\title{
Magnetotelluric characterization of the Alhama de Murcia Fault (Eastern Betics, Spain) and study of magnetotelluric interstation impedance inversion
}

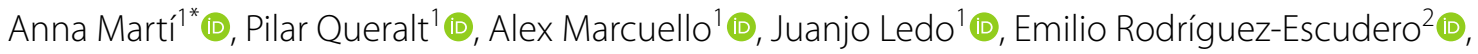 \\ José Jesús Martínez-Díaz $z^{3}$ (i), Joan Campanyà ${ }^{4}$ a and Naser Meqbe ${ }^{5,6}$ (i)
}

\begin{abstract}
The Lorca earthquake (May 11th, 2011, Mw 5.2) stands as the most destructive one in Spain over the last 50 years, interpreted as having occurred in an intersegment zone of the strike-slip Alhama de Murcia Fault (AMF) (Eastern Betics, Spain). Magnetotelluric data were acquired along a profile to the SW of Lorca (La Torrecilla profile), to characterize its signature at depth, as part of the multidisciplinary project "INTERGEOSIMA". Given the short distance between stations, some station pairs were recorded simultaneously, with magnetic sensors in only one of them. In order to properly understand the resulting impedances (called interstation impedances), and the effects of inverting them, we used synthetic models to compare the impedances and the interstation impedances and to analyze the corresponding inversion results, together with the inversion of the quasi-impedance (inversion of the interstation impedances, considering them as impedances). The results are sensitive to the location of the magnetic sensors and the resistivity underneath, but in general the use of the quasi-impedances in the inversion can be considered a valid procedure. Both the $2 \mathrm{D}$ and the $3 \mathrm{D}$ resistivity models obtained through the inversion allowed us to complement the previous ERT models and represent the continuation of the main fault gouge in depth showing its extension towards the SE.
\end{abstract}

Keywords: Magnetotellurics, Alhama de Murcia Fault, Interstation impedance inversion

\section{Introduction}

The Alhama de Murcia Fault (AMF) is an $87-\mathrm{km}-$ long, SW-NE oriented left-lateral strike-slip fault located in the southeast of the Iberian Peninsula. It belongs to the Eastern Betics and most of the damaging historical earthquakes $(\mathrm{Mw}>6.5)$ in the area are related to its structure (Fig. 1). The Lorca earthquake (Mw 5.2, May 11th, 2011) was generated by the reactivation of one segment of this fault (López-Comino et al. 2012; Martínez-Díaz et al.

\footnotetext{
*Correspondence: annamarti@ub.edu

1 Institut Geomodels, Departament de Dinàmica de la Terra i de l'Oceà, Facultat de Ciències de la Terra, Universitat de Barcelona, 08028 Barcelona, Spain

Full list of author information is available at the end of the article
}

2012b), raising awareness about the need for a better understanding of its internal structure through periodic monitoring.

Figure 1 shows the main trace of the Góñar-Lorca section of the AMF. Since the other sections of the AMF consist of 2 or 3 branches, elucidating the subsurface structure of the AMF to the SW of Lorca has important implications for not only understanding the detailed structure and distribution of its deformation, but also for better quantifying its seismic hazard. For instance, important infrastructures are at risk such as the Rafael Mendez General Hospital, located just $200 \mathrm{~m}$ to the south of the main trace.

In order to obtain a geoelectrical model of the fault zone, we carried out a magnetotelluric (MT) survey, part 

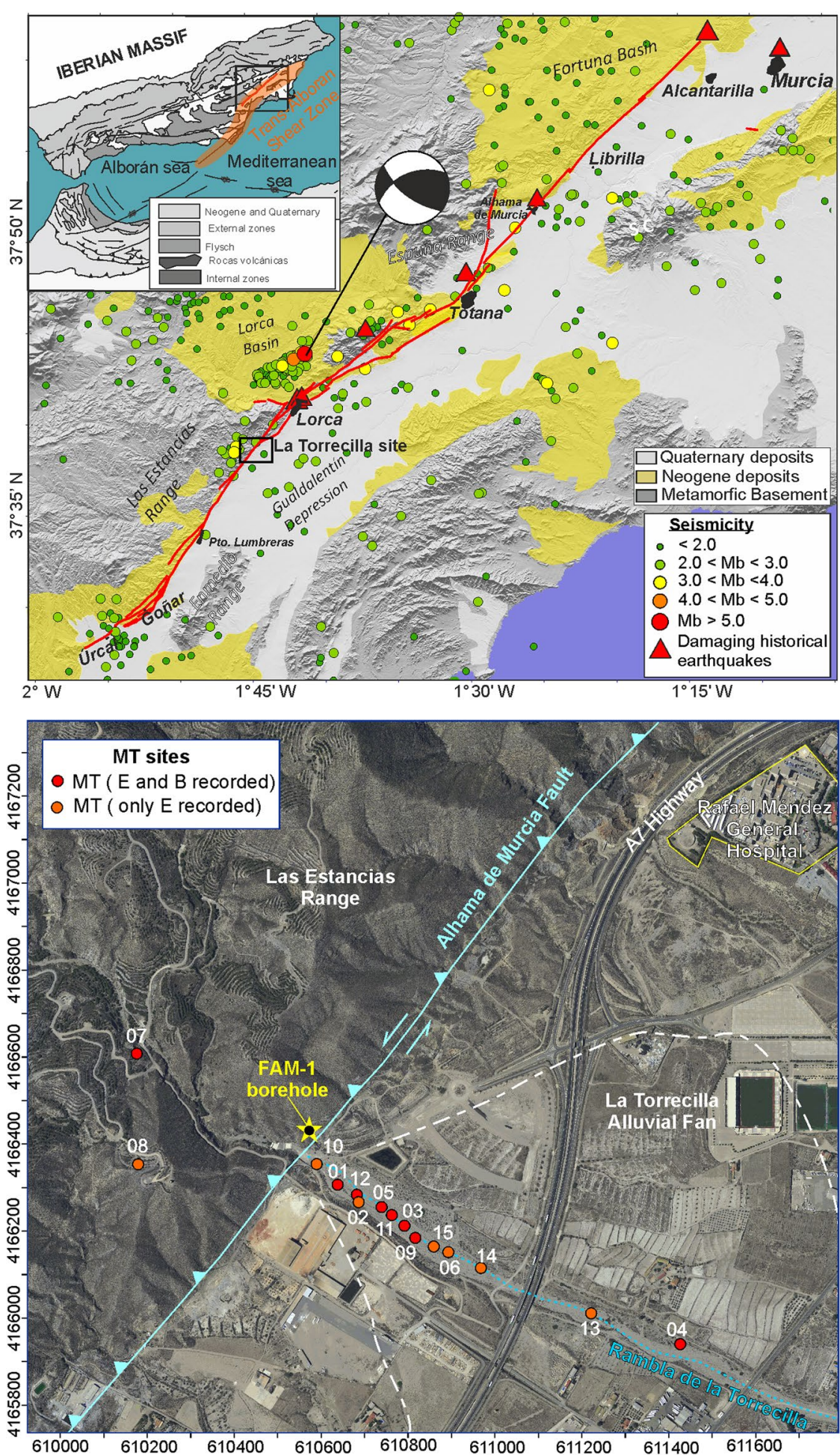

Fig. 1 Top: inset and geological map of the Alhama de Murcia Fault (red trace), epicenters of instrumental and historical earthquakes ( $M>1$; between 500 A.D. and 2012) and the Mw 5.2, 2011 Lorca earthquake focal mechanism. Black rectangle limits the area of the Torrecilla Survey (modified from Martínez-Díaz et al. 2016a). Bottom: aerial view of the Rambla de la Torrecilla area and location of MT sites acquired. The blue line is the main trace of the Alhama de Murcia Fault (Source: Google Earth) 
of the INTERGEOSIMA project (Martínez-Díaz et al. 2016a, b), which consisted of a 1.5-km profile in La Torrecilla, SW of Lorca that crossed the main trace of the fault. Given the short length of the profile and the fact that some stations were located close to electrical lines (hence, generating high magnetic fields that can saturate the sensors), some pairs of stations were recorded simultaneously, with magnetic sensors in only one of them (Fig. 1).

The MT method is a non-invasive technique (see Chave and Jones 2012) that allows characterizing the electrical resistivity of the subsoil. This can then be related to the type of materials and/or to structural changes, such as the presence of fluids or the continuation of a fault trace in depth, as shown in studies performed on the Dead Sea Transform Fault (Ritter et al. 2003), San Andreas Fault (Becken and Ritter 2012), and on the Iberian Peninsula, the Maladeta Fault in the Pyrenees (Ortuño et al. 2008) as well as the Eastern Betics' Carboneras Fault (Queralt et al. to be submitted to Terra Nova).

The main hypothesis of the MT method is that the electric and magnetic fields are of natural origin (electrical thunderstorms and ionosphere-magnetosphere interactions) and have a distant source. However, electromagnetic signals from anthropogenic (and nearby) sources are superposed upon the natural fields (Escalas et al. 2013). These sources cannot be neglected, especially near urban areas, and are caused by electrical transformers and power lines (creating a magnetic field, which can itself induce electrical currents), electric train lines, wind turbines, vehicle circulation, and water pipes.

The time variations of the horizontal electric and magnetic fields are measured at the surface, from which the frequency dependent impedance tensor $(Z)$ and the corresponding apparent resistivities and phases are obtained. When the simultaneous horizontal electric and magnetic field time variations are registered at different locationselectric from a local site and magnetic from a neighboring site-, the resulting transfer functions $(2 \times 2$ tensors with complex components) differ from the local impedance tensor. We name them interstation impedances, following the notation of interstation transfer functions in Campanyà et al. (2014), which points to the differences between the local and interstation transfer functions. Other authors refer to them as pseudo-remote reference impedances (Muñoz and Ritter 2013), or inter-site impedances (Kruglyakov and Kuvshinov 2019), which have been implemented in inversion algorithms (e.g., Kruglyakov and Kuvshinov 2019). If the interstation impedancetogether with its corresponding apparent resistivities and phases-is represented, analyzed and inverted as if it were a local impedance (i.e., approaching both the electric and magnetic fields coming from the same site), we can refer to them as quasi-impedances ( $\mathrm{qZ}$, also following the notation "quasi-MT transfer functions", in Campanyà et al. 2014), quasi-apparent resistivity (q-apparent resistivity) and quasi-phase (q-phase), respectively. Hence, ZI and $\mathrm{qZ}$ are the same, but we refer to it as ZI when it is analyzed and inverted taking into account the real locations of the local site (where the electric field variations have been registered) and of the neighboring site (where the magnetic field variations have been registered); whereas qZ is analyzed and inverted by approaching that both the electric and magnetic fields have been registered at the same site (Fig. 2, top right box). The reason for using qZ, instead of ZI, is that most of the available software for analyzing and modeling MT data use the local impedances $Z$. Hence, it is necessary to consider what the validity of this approximation is.

With the aim of better understanding the interstation impedances and the effects of inverting them for the Torrecilla profile, in the first part of the paper we present the results from synthetic tests using interstation impedance (ZI), which was implemented into the ModEM code (Egbert and Kelbert 2012; Kelbert et al. 2014) to identify the differences between the $Z$ and $Z I$ responses; and the effects of inverting $Z$, ZI or qZ.

In the second part, we focus on the Torrecilla survey itself, for which we performed a $2 \mathrm{D}$ inversion that allowed us to depict the main geoelectrical structures and relate them to the subsurface geology. We also carried out $3 \mathrm{D}$ inversions, treating the responses either as $\mathrm{ZI}$ or as qZ, and extending the 2D model in order to assess the robustness of its structures.

\section{Interstation impedance vs quasi-impedance inversion-synthetic tests for fault detection}

In the analysis of the responses and inversions using $Z$, ZI and $\mathrm{qZ}$, we followed a methodology similar to the work of Campanyà et al. (2016), which focused on the interstation horizontal magnetic tensor $(H)$ (the relationship between the horizontal magnetic fields at two locations), but we adapted it to the calculation of interstation impedances (ZI). Departing from different synthetic models, we calculated the corresponding impedances $(Z)$ and interstation impedances (ZI), using one or several configurations (relative locations between local and neighboring sites); and then performed three types of inversion: inverting $Z$, inverting ZI, and inverting qZ. We considered two models, for which both the forward problem and the inversions were solved using the ModEM code, adapted to the calculation of ZI. In both models, we only considered one or two neighboring sites to better isolate the effects on the inversion of ZI or qZ.

The main results from the two models are explained next. The details of the calculation of the forward 


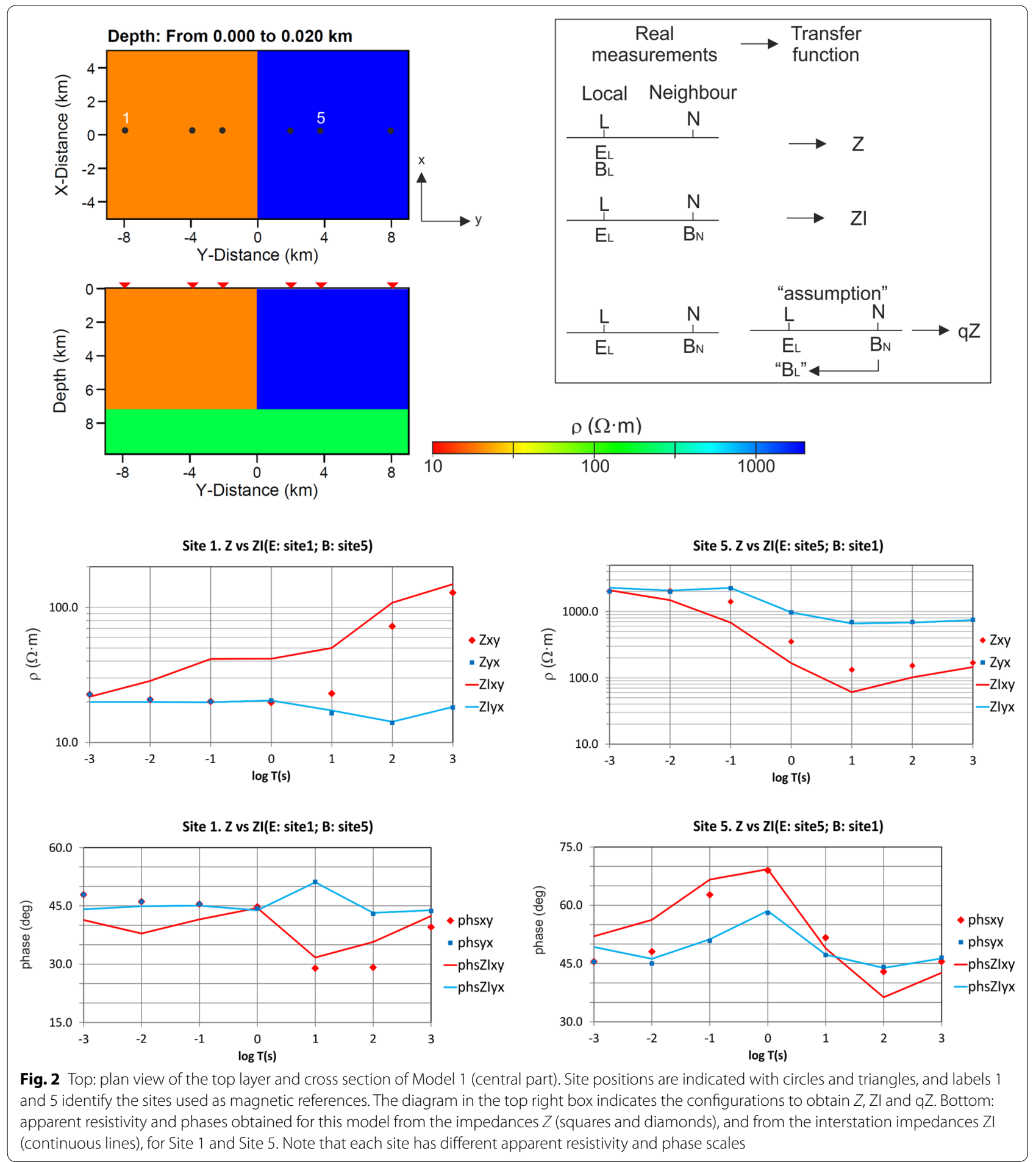

responses and the inversions carried out can be found in Additional file 1.
Model 1: vertical contact (2D)

In order to illustrate a very simple case, the first synthetic model was a NS-oriented vertical contact (2D) separating two media of $20 \Omega \cdot \mathrm{m}$ (west side) and $2000 \Omega \cdot \mathrm{m}$ (east side); underlain by a $200 \Omega \cdot \mathrm{m}$ basement. The 
forward model responses $(Z)$ were calculated for 7 periods $(0.001-1000 \mathrm{~s})$ at 6 sites, distributed symmetrically along a profile crossing the contact perpendicularly. ZI was calculated for the same periods at Site 1 using the magnetics from Site $5(E: 1 ; B: 5)$; and for Site 5 using the magnetics from Site $1(E: 5 ; B: 1)$. Figure 2 shows the plan view and a cross section of the model and the offdiagonal apparent resistivities and phases (the diagonal components were practically null) calculated at Sites 1 and 5, from the impedance (dots) or from the interstation impedance (lines). The apparent resistivities obtained from $Z$ show equal $x y$ (transversal electric, TE) and $y x$ (transversal magnetic, TM) curves at short periods that split in the middle (Site 1, on the conductive side) or short (Site 5 , on the resistive side) periods due to the vertical contact. The curves computed from ZI differ from those of $Z$ mainly in the $x y$ (TE) component. In the case of Site 1 , the $x y$ apparent resistivity is higher because the magnetic field is taken from the resistive medium, which has a lower magnetic field $\left(B_{y}\right)$, and hence it results in a higher value of the quotient $E_{x} / B_{y}$. At Site 5 the apparent resistivity is lower because the contrary occurs: the magnetic field is taken from the conductive medium, with a higher magnetic field $\left(B_{y}\right)$, resulting in a lower quotient $\left(E_{x} / B_{y}\right)$. This is also reflected in the $x y$ phases, which are different for both sites.

We carried out the following inversions:

A. Inversion of $Z$ at all sites.

B1. Inversion of $\mathrm{ZI}$ at Site $1(\mathrm{E}: 1 ; \mathrm{B}: 5)$ and $Z$ at the rest of sites.

B2. Inversion of the quasi-impedance (qZ) at Site 1 $(\mathrm{E}: 1 ; \mathrm{B}: 5)$ and $Z$ at the rest of the sites.

C1. Inversion of $Z \mathrm{I}$ at Site $5(E: 5 ; B: 1)$ and $Z$ at the rest of the sites.

C2. Inversion of the quasi-impedance (qZ) at Site 5 $(E: 5 ; B: 1)$ and $Z$ at the rest of the sites.

$Z$ and $Z$ I inversions resulted in similar models (A, B1, and $\mathrm{C} 1$ ). Inversion $\mathrm{B} 2$ (qZ with $E$ measured above a conductor, and $B$ above a resistor), produced a zone slightly less conductive below Site 1 (Fig. 3). Inversion C2 (qZ with $E$ above a resistor and $B$ above a conductor) did not add any clear artifact under Site 5 (Fig. 3), but the resistivity between Site 5 and Site 6 is lower than for the models from the other inversions. In all three cases the root mean square (rms) value is close to 1 . These results are consistent with what was expected from the evaluation of the responses. From this, we see how the choice of the neighboring site does not affect the results of inverting ZI (B1 and C1); but when $\mathrm{qZ}$ is used instead, the results depend on the location of the neighboring site where the magnetic field is calculated.

\section{Model 2: fault model with a 3D shallow conductor}

This model was created to simulate a possible geoelectrical structure for the Torrecilla profile data in the AMF. The model (Fig. 4) has a 1D background structure that represents, from top to bottom: $700 \mathrm{~m}$ of colluvial sediments $(2000 \Omega \cdot \mathrm{m}), 800 \mathrm{~m}$ of plio-quaternary materials $(100 \Omega \cdot \mathrm{m})$ and the Paleozoic basement $(500 \Omega \cdot \mathrm{m})$. This structure was cut by a NS directed quasi-vertical fault zone having a thickness of $200 \mathrm{~m}$, a resistivity of $10 \Omega \cdot \mathrm{m}$, and a $360 \mathrm{~m}$ side superficial block of $30 \Omega \cdot \mathrm{m}$ to account for the 3D effects.

The impedances $Z$ were computed at 6 sites along a $1.5 \mathrm{~km} \mathrm{E}-\mathrm{W}$ profile. ZI was calculated by taking the electric field from Site 4 (on top of the conductive block) and the magnetic field from Site 6 (over the resistive part). The apparent resistivities and phases obtained from the four components of $Z$ and ZI at Site 4 are represented in Fig. 4. The shortest periods (both diagonal and off-diagonal components) are the ones that vary the most, given the small scale of the model structures. Apparent resistivities from ZI are higher than the ones from $Z$ because in $Z I$ the magnetic field is taken from the resistive medium, which has a lower value and hence a higher $E / B$ ratio.

The following inversions were carried out:

A. Inversion of $Z$ for all sites.

B1. Inversion of $Z$ I for Site $4(E: 4 ; B: 6)$ and $Z$ at the rest of the sites.

B2. Inversion of the quasi-impedance (qZ) at Site $4(\mathrm{E}: 4 ; \mathrm{B}: 6)$ and $Z$ at the rest of the sites.

The models obtained from the three inversions are similar (Fig. 5) and recover the large scale structures (the resistive background and the fault). The main difference is that inversion $\mathrm{B} 2$ ( $\mathrm{qZ}$ ) does not reproduce so well the shape of the local conductor below Site 4, as a consequence of using a less intense magnetic field than what would correspond to a conductive area. Focusing on the synthetic data (forward responses of Model 2) and the responses of the resulting models at Site 4 (Fig. 5), the rms for the inversion of $\mathrm{qZ}$ is slightly higher than for ZI (Additional file 1), although the curves of the data and model responses follow a similar trend as for the inversion of $Z$. The $x y$ component is similarly fitted for the three cases, whereas the $y x$ component does not fit so well for any of the three inversions. The diagonal components are over-fitted due to their large relative errors (Fig. 5). 

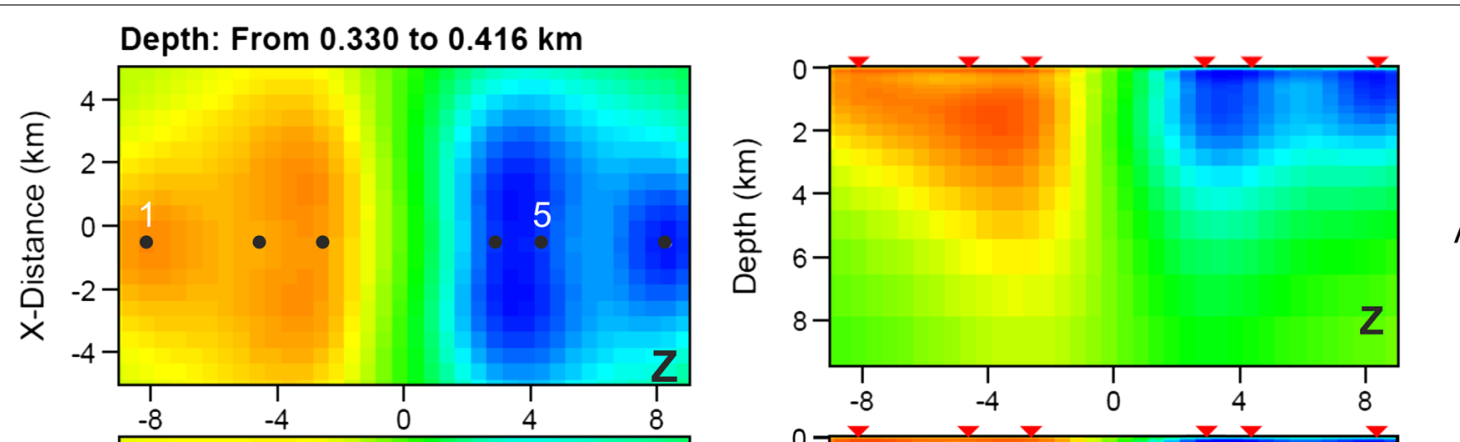

A
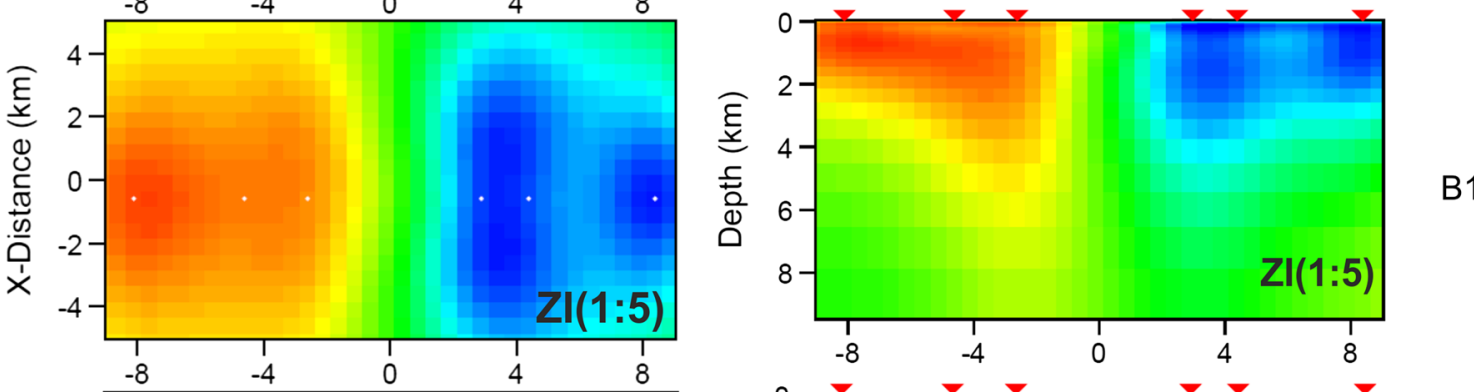

B1

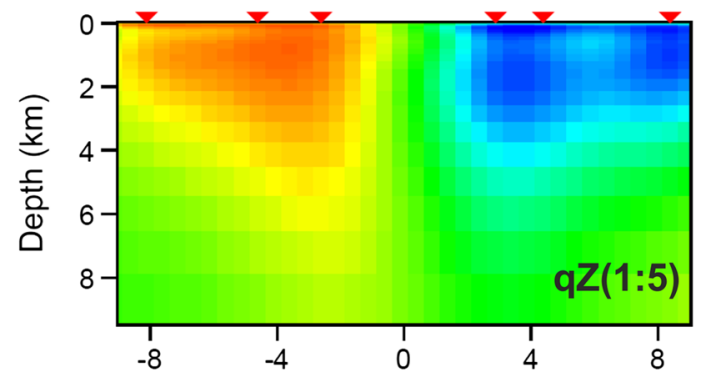

B2
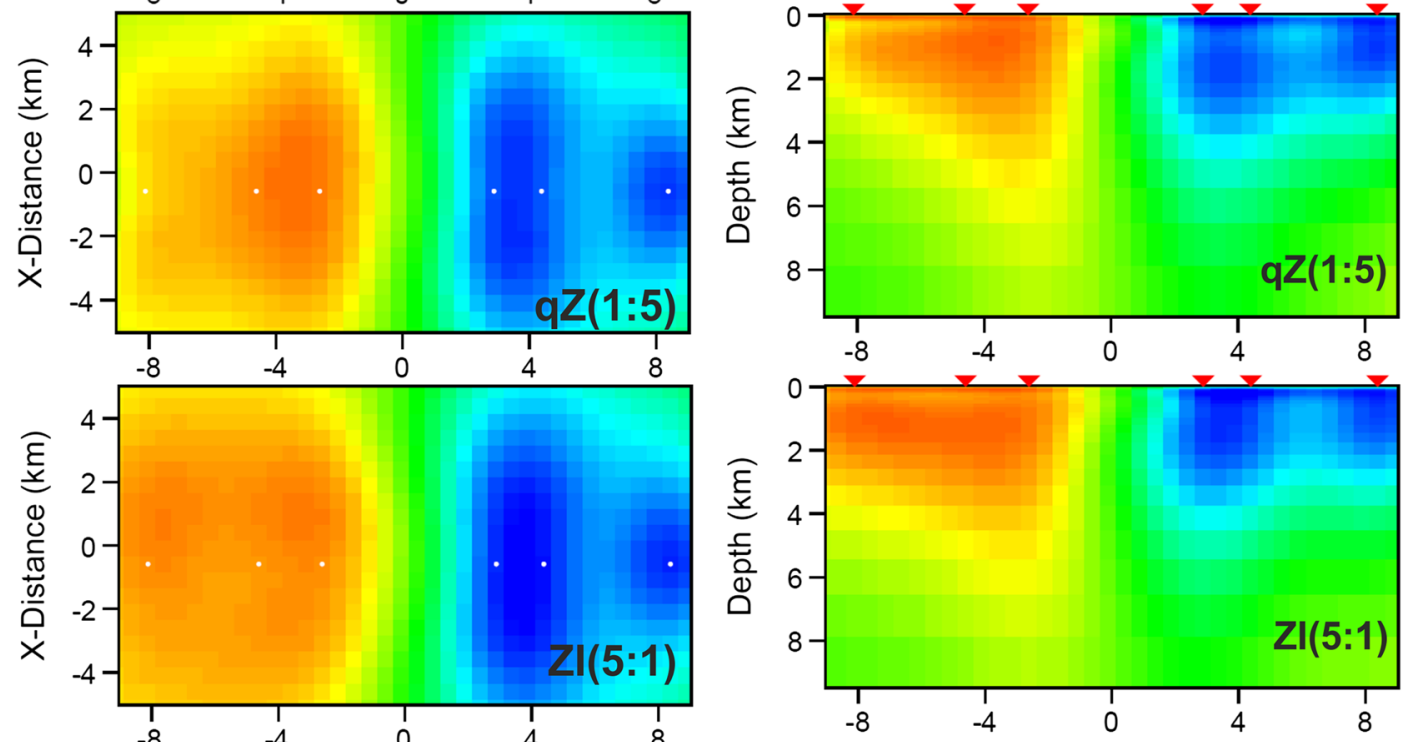

C1
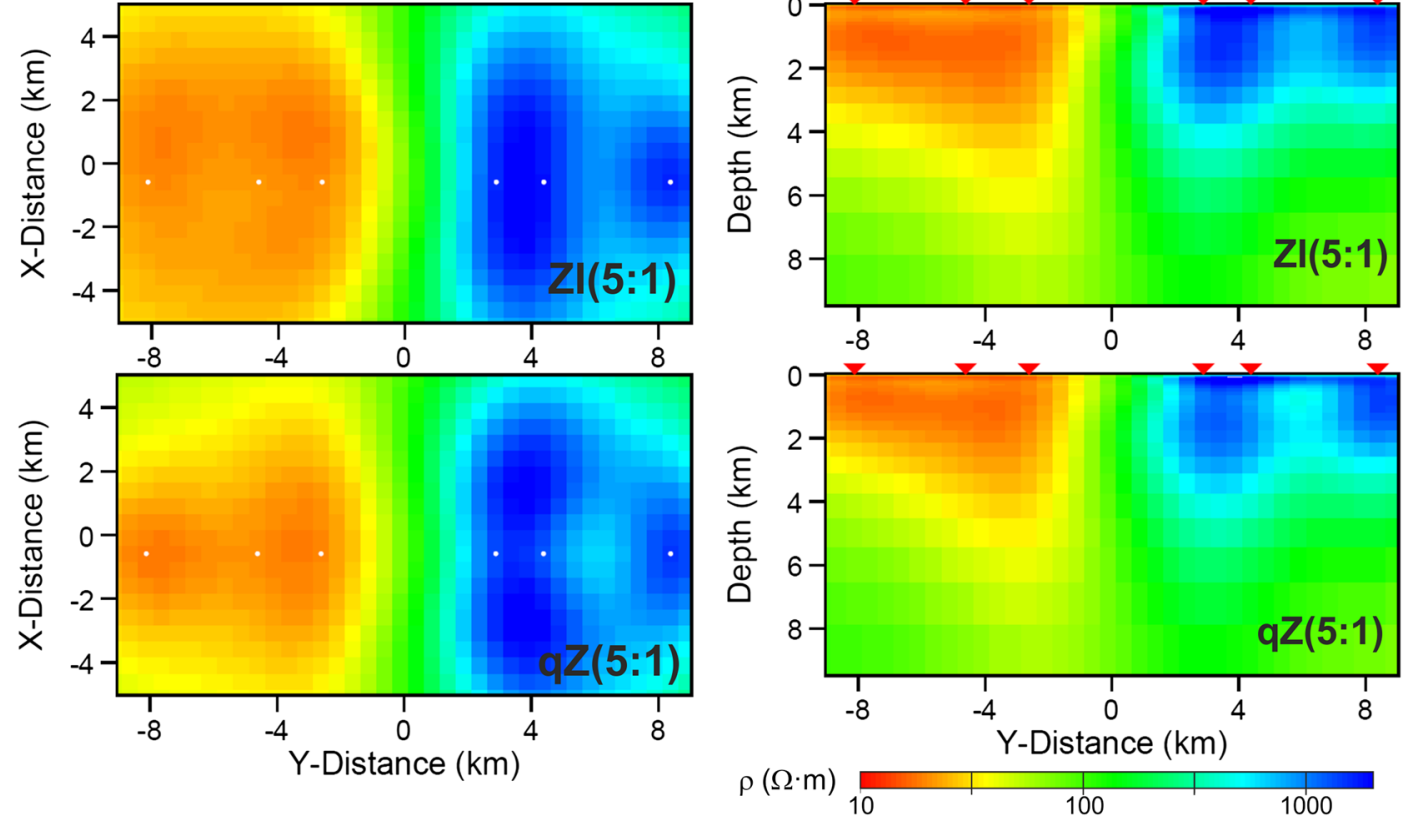

C2

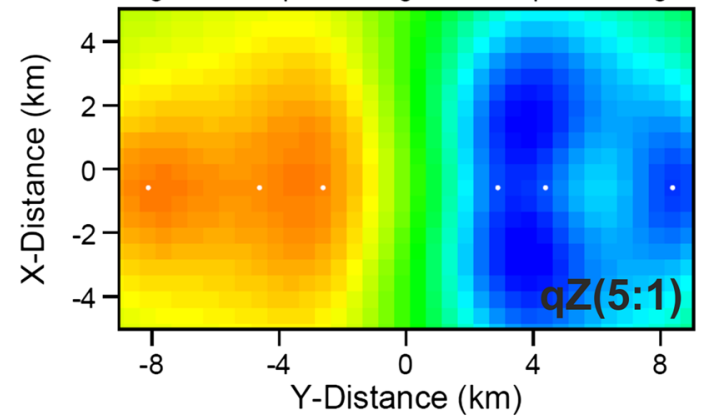

$\rho(\Omega \cdot m)$

Fig. 3 Plan views and cross sections along the profile of the models obtained from inverting Model 1 synthetic data: $\mathbf{a}$ the impedance $Z$ (top), $\mathbf{b}$ the interstation impedance ZI (E:1; B:5) and quasi-impedance $\mathrm{qZ}$ (E:1;B:5) (middle), as well as c ZI (E:5;B:1) and qZ (E:5;B:1) (bottom) 

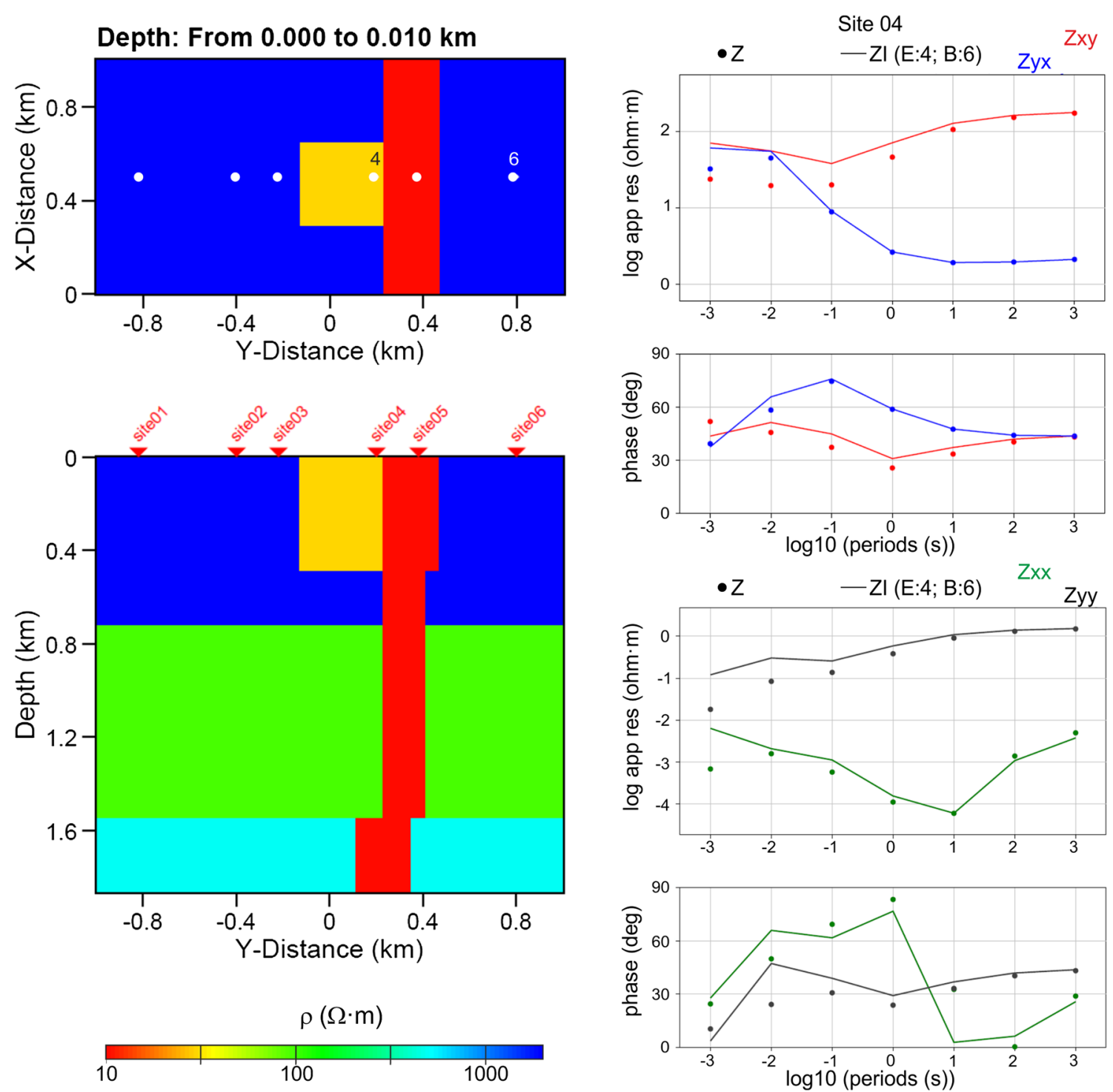

Fig. 4 Left: plan view at the surface (top) and cross section beneath the profile (bottom) for synthetic Model 2. Right: responses calculated at Site 4 from $Z$ (dots) and ZI (lines): $x y$ and $y x$ components (top) and $x x$ and $y y$ components (bottom)

Table 1 summarizes the forward and inversion tests performed for the two models. We are able to isolate the results by inverting ZI or qZ. As such, we confirm the validity of the inversion of $\mathrm{ZI}$, and the dependence of the inversion of $\mathrm{qZ}$ on the location of the neighboring site. However, the inversion of $\mathrm{qZ}$ for the fault model (Model 2) did recover the main structures. With this in mind, and in the context of our study area, with sites close to each other, we expect that the inversion of $\mathrm{qZ}$ responses will be a valid approach.

\section{The Alhama de Murcia Fault magnetotelluric survey}

Geological and geophysical setting

\section{The Alhama de Murcia Fault in the context of the Betic}

\section{Cordillera}

The Alhama de Murcia Fault (AMF) (Bousquet 1979) is an $87-\mathrm{km}$-long, $\mathrm{N} 40^{\circ} \mathrm{E}-\mathrm{N} 65^{\circ} \mathrm{E}$, reverse component, leftlateral strike-slip fault located in the northeastern part of the Eastern Betics Shear Zone (De Larouziére et al. 1988) (Fig. 1). The AMF is located in the Betics Internal Zone, which consists of a thrust stack of Paleozoic, Mesozoic, and Paleogene rocks developed during the Alpine orogeny (Azañón et al. 2002). The Nevado-Filábride, 


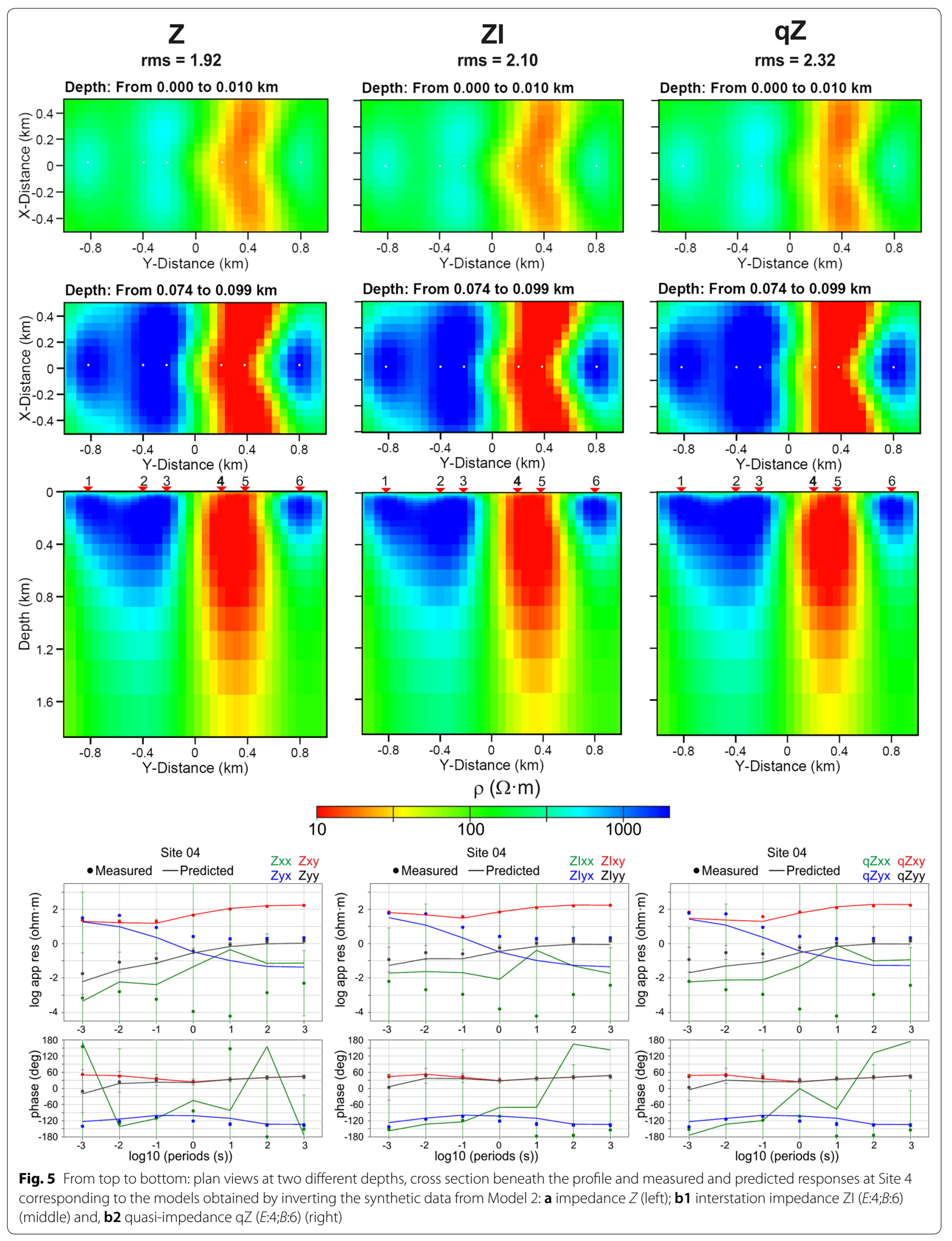


Table 1 Summary of the 2 models used to calculate the responses and to test the inversion of the interstation impedances

\begin{tabular}{|c|c|c|c|c|c|c|c|}
\hline \multirow[b]{2}{*}{$\begin{array}{l}\text { Model } 1 \text { (vertical } \\
\text { contact) }\end{array}$} & \multicolumn{4}{|c|}{ Forward ${ }^{\mathrm{a}}$-site configuration } & \multicolumn{3}{|c|}{ Inversion } \\
\hline & Conductive & & Resistive & & $z$ & $\mathrm{ZI}$ & $q Z$ \\
\hline A & 123 & & 456 & & $\checkmark \checkmark$ & & \\
\hline B & $1: 523$ & & 456 & & & $\checkmark \checkmark$ & $\checkmark$ \\
\hline C & 123 & & $45: 16$ & & & $\checkmark \checkmark$ & $\checkmark$ \\
\hline $\begin{array}{l}\text { Model } 2 \\
\text { (fault + block) }\end{array}$ & 1D & Block & Fault & 1D & $z$ & $\mathrm{ZI}$ & $q Z$ \\
\hline A & 123 & 4 & 5 & 6 & $\checkmark \checkmark$ & & \\
\hline B & 123 & $4: 6$ & 5 & 6 & & $\checkmark \checkmark$ & $\checkmark$ \\
\hline
\end{tabular}

The forward column indicates at which sites $Z$ and $Z$ I were calculated. The inversion column indicates which inversions were performed ( $Z$, $Z$ I or qZ) and the validity of the obtained models (good $\checkmark \checkmark$, or regular $\checkmark$ )

a One number indicates the site number; two numbers separated by a colon indicates where the site's electric and magnetic fields were recorded, respectively

Alpujárride and Maláguide are the principal tectonic complexes (Egeler and Simon 1969) that were later reactivated through low-angle normal faults due to an extensional tectonics regime (Galindo Zaldívar et al. 1989; Jabaloy et al. 1992; Martínez-Martínez and Azañón 1997). In the neotectonic period (the last 9 My) a NNWSSE compressional stress field became dominant and the AMF behaved as a transpressional oblique-slip structure (Montenat 1990; Martínez-Díaz et al. 2012a). According to results from morphotectonics, paleoseismic and geodesic studies, the AMF, together with the Palomares Fault, accommodates $\sim 1.0 \mathrm{~mm} /$ year of the approximately $5 \mathrm{~mm} /$ year of convergence between the Nubian and Eurasian plates (Echeverría et al. 2013; Ferrater et al. 2016). The AMF is one of the largest faults of the Eastern Betics Shear Zone (Silva et al. 1993), and the cause for an important number of damaging historical earthquakes that have occurred in this area.

The AMF is active as a transpressional structure at least since the Upper Miocene (Tortonian) (Montenat et al. 1987). Before that, the AMF behaved as a normal or transtensional fault that generated an elevated relief along the present Guadalentín depression. The relative vertical movements of the hanging wall favored the formation of several Neogene basins: the Lorca and the Fortuna basins (Fig. 1) (Montenat et al. 1987; Silva 1994; Martínez-Díaz 1998). Since the Tortonian the area has been dominated by a horizontal shortening direction oriented $\mathrm{N} 150^{\circ} \mathrm{E}$. The tectonic inversion of the AMF produced by this stress field induced the formation of the Guadalentín depression and the uplift of the Lorca and Fortuna Miocene basins as well as the Las Estancias, La Tercia, and the Espuña ranges in the NW wall of the fault (Montenat 1990; Herrero-Barbero et al. 2018).
In contrast with other segments, for which deformation is distributed among several branches, in the Góñar-Lorca segment most of the displacement on the AMF is restricted to a single branch (Fig. 1). The hanging wall in this sector is made up of metamorphic rocks that form the Las Estancias range. The foot wall controls the position of the Guadalentín tectonic depression filled by Quaternary sediments. The fault zone at this site shows a 100-m-wide shear zone that runs along the mountain front. This shear zone includes rocks from Palaeozoic and Triassic units of the Alpujárride and Maláguide complexes that form a 20-m-wide band of fault gouge oriented NE-SW, bounding the undeformed schists of the range; to the SE there is a parallel band of highly deformed Miocene rocks (Fig. 6). The Quaternary alluvial deposits overlying the shear zone are offset and tilted by the recent activity of the fault along the southeast edge according to observations in several trenches and an exploratory borehole made by Martínez-Díaz et al. (2016b).

\section{Structure of the AMF and selection of the study location}

Geometrical variations along the fault zone of the structure and geomorphic expression and changes in seismicity rate, were used by Martínez-Díaz et al. (2012a) to divide the AMF into four sections (Fig. 1): (1) Góñar-Lorca $\left(\mathrm{N} 40^{\circ} \mathrm{E}\right),(2)$ Lorca-Totana $\left(\mathrm{N} 60^{\circ} \mathrm{E}\right),(3)$ Totana-Alhama de Murcia ( $\mathrm{N} 40^{\circ} \mathrm{E}$ ), and (4) Alhama de Murcia-Alcantarilla (N45 $\mathrm{E})$. The Lorca earthquake (Mw 5.2, May 11th, 2011) was generated by the reactivation of the SW end of the Lorca-Totana section (López-Comino et al. 2012; Martínez-Díaz et al. 2012b). This event raised awareness about the need for a better 

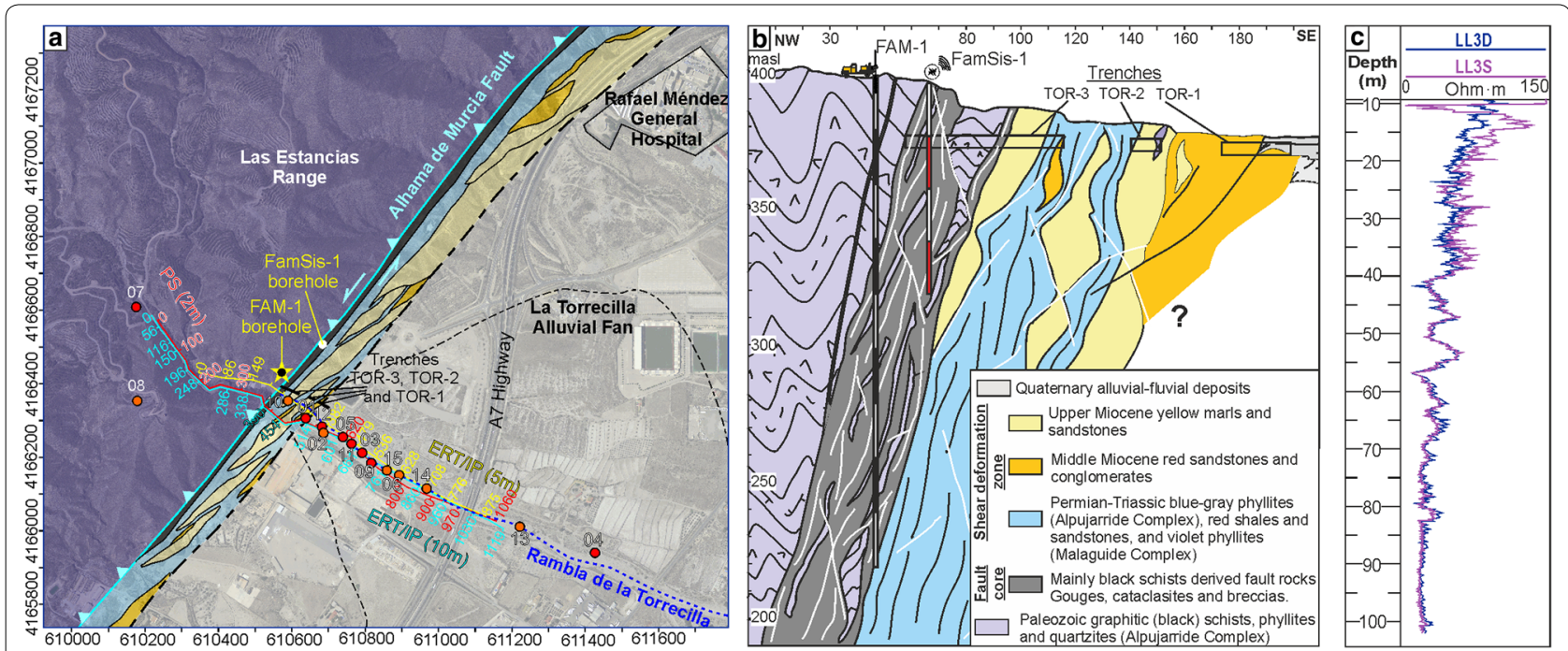

Fig. 6 a Combined aerial photo and geological map of the La Torrecilla area showing the main trace of the AMF and the geological units compounding the fault zone (b). The location of the MT, the FAM-1 and FamSis-1 boreholes are also shown, in addition to the position of the geophysical profiles in Fig. 9. b Geological cross section constructed from borehole logging information and trenches Tor-1, Tor-2, and Tor-3. c Resistivity log from FAM-1, up to 100 m depth (modified from Martínez-Díaz et al. (2016b))

understanding of the internal structure of the fault and for periodic monitoring of it. In this sense, INTERGEOSIMA-QUAKESTEP interdisciplinary projects aim to identify and understand the structure and seismogenic behavior of the AMF over the short, middle and long term (Martínez-Díaz et al. 2016a, b). A paleoseismic study of the different segments and intersegment zones of the fault, structural characterization of the fault through geophysical methods, rheological analysis from trenches, and an exploration borehole are currently in progress and are providing new data (Martínez-Díaz et al. 2018; Rodríguez-Escudero et al. 2018). The AMF was also monitored through a dense GNSS network to discriminate the slip rate for each section (Staller-Vázquez et al. 2018).

We selected the Góñar-Lorca section to carry out the geophysical analysis because in this sector the structure of the AMF is (according to available surface geology data) the one with the simplest structure, with most of the deformation apparently accumulated in a single branch. Therefore, the observation of its structure at depth would be a priori, easier or at least feasible.

\section{Previous geophysical data}

In the Góñar-Lorca segment (Fig. 6), the FAM-1 borehole (174 $\mathrm{m}$ depth) was drilled in the shear zone with the most exhumation (Rambla de la Torrecilla, $3 \mathrm{~km} \mathrm{SW}$ of Lorca). The borehole core recovery and the information from the three excavated trenches allowed determination of the detailed structure of the fault zone
(Rodríguez-Escudero 2017; Rodríguez-Escudero et al. 2018). A preliminary geological interpretation (Fig. 6a, b) shows that the fault zone has a minimum width of $150 \mathrm{~m}$ with a $70^{\circ} \mathrm{NW}$ dip. From NW to SE the observed units are graphitic schists from the Alpujárride Complex, a clay rich blackish fault gouge containing graphite, a mélange of blue-gray phyllite fault gouge with Miocene marls, Miocene sandstones and Quaternary alluvial limes and gravels (Martínez-Díaz et al. 2016b; RodríguezEscudero 2017). The resistivity log reached $100 \mathrm{~m}$ depth and showed a rapid decrease in resistivity from $70 \mathrm{~m}$ depth where the black fault gouge appears, varying from approximately 100 to $20 \Omega \cdot \mathrm{m}$ (Fig. 6c).

Also in the Torrecilla area, nearly co-located electrical resistivity tomography (ERT) as well as refraction and reflection seismic profiles were surveyed crossing the main fault trace (Ardanaz et al. 2018).

The ERT model (Fig. 9a) shows middle and high resistivities $(150 \Omega \cdot \mathrm{m}$ to more than $1000 \Omega \cdot \mathrm{m})$ towards the NW (Unit U1), interpreted as Paleozoic lithologies. In the central part of the model (400-550 m), low resistivities ( 1 to $20 \Omega \cdot \mathrm{m}$, coincident with the values obtained from the FAM-1 resistivity $\log$ ) are associated with the main fault zone (Unit U2). Toward the SW, high resistivity values (150 to $1000 \Omega \cdot \mathrm{m})$ are associated with recent alluvial Quaternary conglomerates (Unit U3). Below that, lower resistivities (U4, 20 to $100 \Omega \cdot \mathrm{m}$ ) are related to more cohesive Pleistocene alluvial fan deposits. The contact between $\mathrm{U} 3$ and $\mathrm{U} 4$ presents vertical variations, which 
are related to the faulting. This would support the continuity of the shear zone below the Quaternary deposits.

To this end, we carried out the MT survey in La Torrecilla (Góñar-Lorca segment), in order to better constrain this interpretation and to obtain more information on the structure of the basement, such as to determine the actual width of the shear zone and the possibility of the existence of other blind branches or faults beneath the Quaternary sediments. This survey was also co-located with the previous ERT and seismic profiles (Figs. 1 and 6a).

\section{Data acquisition, processing and analysis}

The Torrecilla survey was carried out in February 2016, where we acquired MT data on a 15 station profile (Fig. 1, bottom), along the Rambla de la Torrecilla. Sites 7 and 8 delimit the survey to the WNW and were located over the Sierra de las Estancias (Alpujárride Complex, Internal Betics), at the farthest distance from the highway, but in an area with the highest topographic relief. They are significantly far from the other sites because of the rugged topography (narrow stream) that made it impossible to install a MT site along it. Sites 1 and 10 were located directly above the fault guge (Fig. 6a). The rest of sites were installed on top of the Quaternary deposits of the Guadalentín depression.

We measured the time variations of the horizontal electric and magnetic fields simultaneously using the ADU06 and ADU07 Metronix systems, with a total duration between 2 and $18 \mathrm{~h}$, depending on the site. Given the short length of the full profile $(1.5 \mathrm{~km})$, and the proximity of some sites to an electrical line, some pairs of stations were recorded simultaneously, with magnetic sensors on just one of them.

Since the location of the survey is very close to the A7 highway and an industrial zone, the time series are sometimes highly contaminated by noise. In order to mitigate this effect, some sites were recorded overnight, where anthropogenic activity was at a minimum, in order to get enough samples and better statistics for the data processing. The contact resistance between the electrodes and the soil presented high values due to low terrain compaction.

After applying a delay filter to remove the $50-\mathrm{Hz}$ noise and its associated harmonics, time series were processed using Mapros (Friedrichs 2003) and ProcMT (Friedrichs 2015) Metronix software based on a robust method. At the sites where both the electric and magnetic field were measured, the outputs were the impedances $(Z)$. At sites where only the electric field was measured (marked in orange color in Fig. 1), the magnetic field was taken from a neighboring site and the time series had to be rewritten so the components of both the electric and magnetic fields started simultaneously and that they had the same duration. In these cases, the outputs were formally the interstation impedances (ZI). However, until the contrary is stated, they are treated as quasi-impedances (qZ), i.e., they are analyzed and inverted as if both the electric and magnetic fields had been measured at the same site, and their related responses will be referred to as regular apparent resistivities and phases. The main reason, as stated in the introduction, is that most of the analysis and modeling tools assume that the responses are the impedances $Z$, and the derived apparent resistivities and phases.

The apparent resistivities and phases were obtained for periods ranging from 0.001 to $1 \mathrm{~s}, 10 \mathrm{~s}$, or $100 \mathrm{~s}$, depending on the total measured time at each site. The data quality was not very good, as the curves in general show several peaks and low coherencies. We carried out a dimensionality analysis using the code WALDIM1.1 (Martí et al. 2009). This analysis (using a threshold of 0.3 , with $5 \%$ data error) (Fig. $7 \mathrm{a}$ ) shows a general 3D data behavior for all frequencies, with just a few $1 \mathrm{D}$ and $2 \mathrm{D}$ cases at the shortest periods. The phase tensor (Caldwell et al. 2004) was also computed and represented for each site and period (Fig. 7b) using MTPy software (Kirkby et al. 2019). The results are very scattered with high skew angle values, supporting general 3D data behavior. However, based on the geology the fact that data were acquired along a single profile and, in order to complement the previous ERT model, we decided to first perform a 2D inversion of the measured data, following a strike direction aligned with the fault trace.

\section{Two-dimensional modeling}

Data were rotated to $45^{\circ} \mathrm{E}$, approximately following the direction of the fault trace, and the rotated $x y$ and $y x$ curves were assigned to the TE and TM modes, respectively. The static shift was corrected, leveling the TE and the TM modes at around $200 \Omega \cdot \mathrm{m}$ for the highest frequencies. This value was taken from the ERT model (Ardanaz et al. 2018), which found resistivity values between 100 and $1000 \Omega \cdot \mathrm{m}$ in its shallowest part, corresponding to colluvial quaternary materials. The resulting curves were then smoothed using D+ (Beamish and Travassos 1992) implemented in the software Winglink ${ }^{\circledR}$, and the frequencies with values that were too far from the smoothed curve were manually deactivated. The rotated original and smoothed curves for three representative sites $(1,11$ and 15$)$ are represented in Fig. 8 . The plots for the rest of sites that will be used in the inversion are represented in Additional file 2: Figure S2-1. 
a
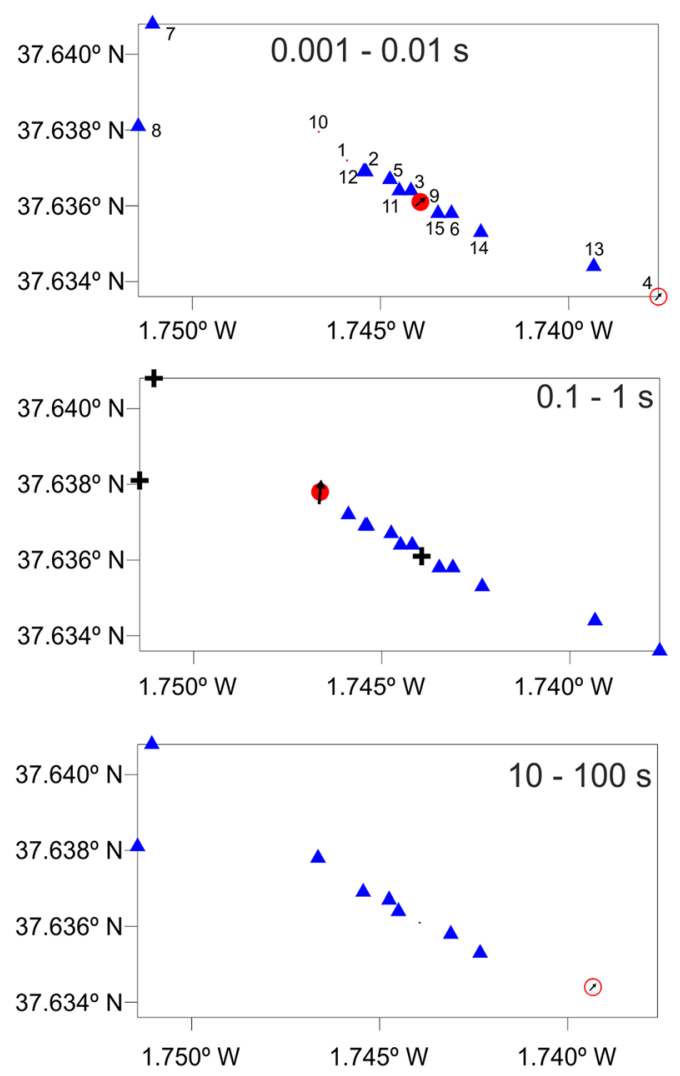

$\begin{array}{ll}1.745^{\circ} \mathrm{W} & 1.740^{\circ} \mathrm{W}\end{array}$
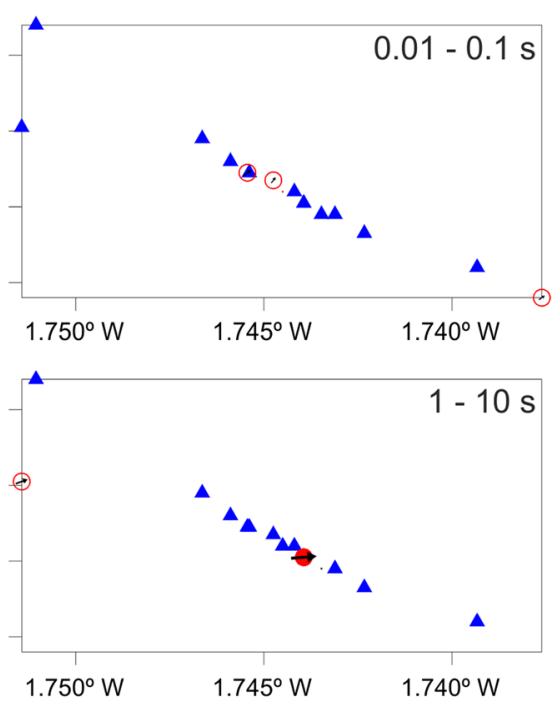

\section{b}
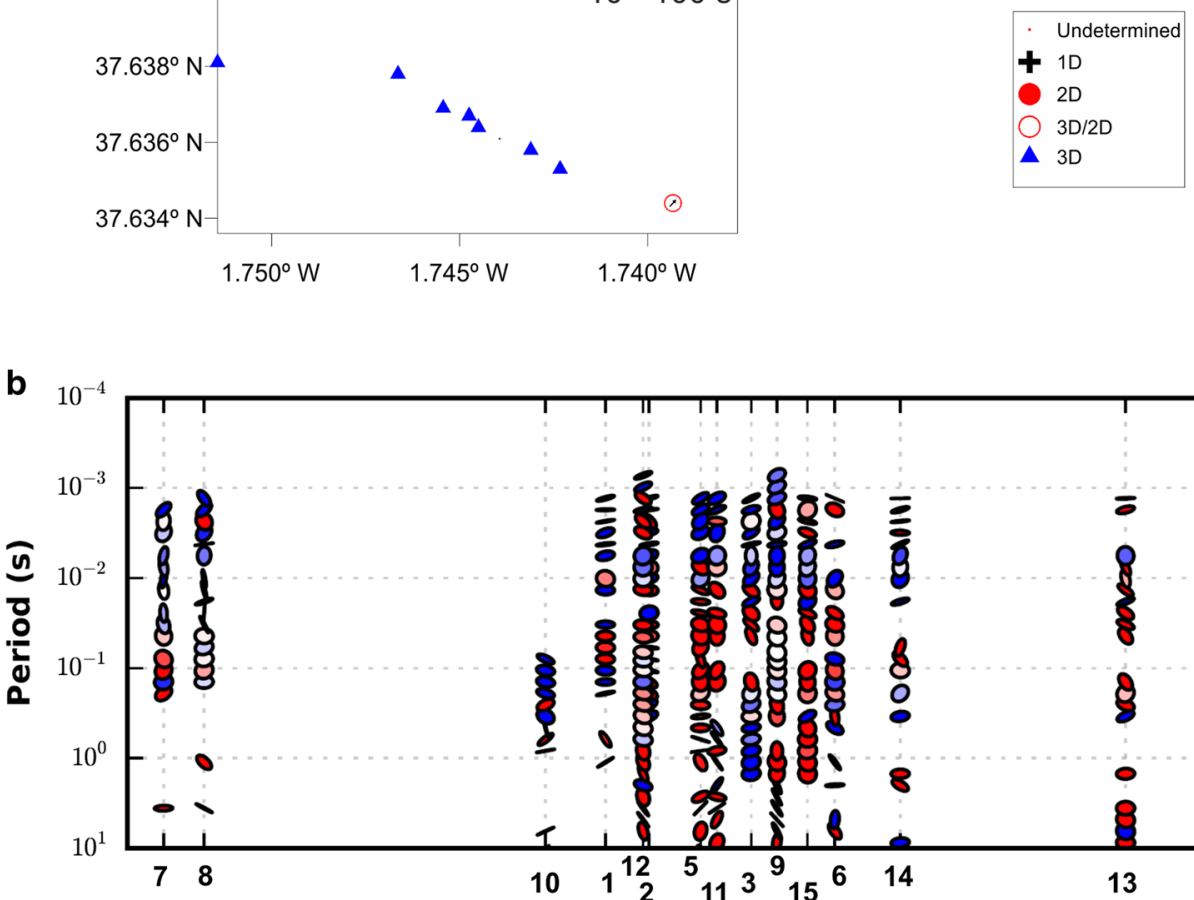

Fig. 7 a Geoelectrical dimensionality maps obtained from the WALDIM code (v1.1) averaged over five period bands for the La Torrecilla survey. Black arrows indicate the strike direction where the structure is $2 \mathrm{D}$ or $3 \mathrm{D} / 2 \mathrm{D}$ and their size is inversely proportional to its error. $\mathbf{b}$ Phase tensor ellipses for each site and period. The color of the ellipses represents the value of the skew angle

For the data inversion we used Mackie's 2D code (Rodi and Mackie 2001) implemented in Winkglink ${ }^{\circledR}$. The initial model had a resistivity of $100 \Omega \cdot \mathrm{m}$, following the topography, and a mesh of 91 rows and 112 columns. The top $50 \mathrm{~m}$ of the model was discretized with $1.5-\mathrm{m}$-size rows, followed by a $1-\mathrm{km}$ range with $15-\mathrm{m}$-size rows, and then increasing by a factor of 1.2 while extending to a depth of $32 \mathrm{~km}$. We discretized the central $2 \mathrm{~km}$ around the sites into columns with widths between 10 and $20 \mathrm{~m}$, increasing by a factor of 1.5 up to an extension of $25 \mathrm{~km}$ on each side. 


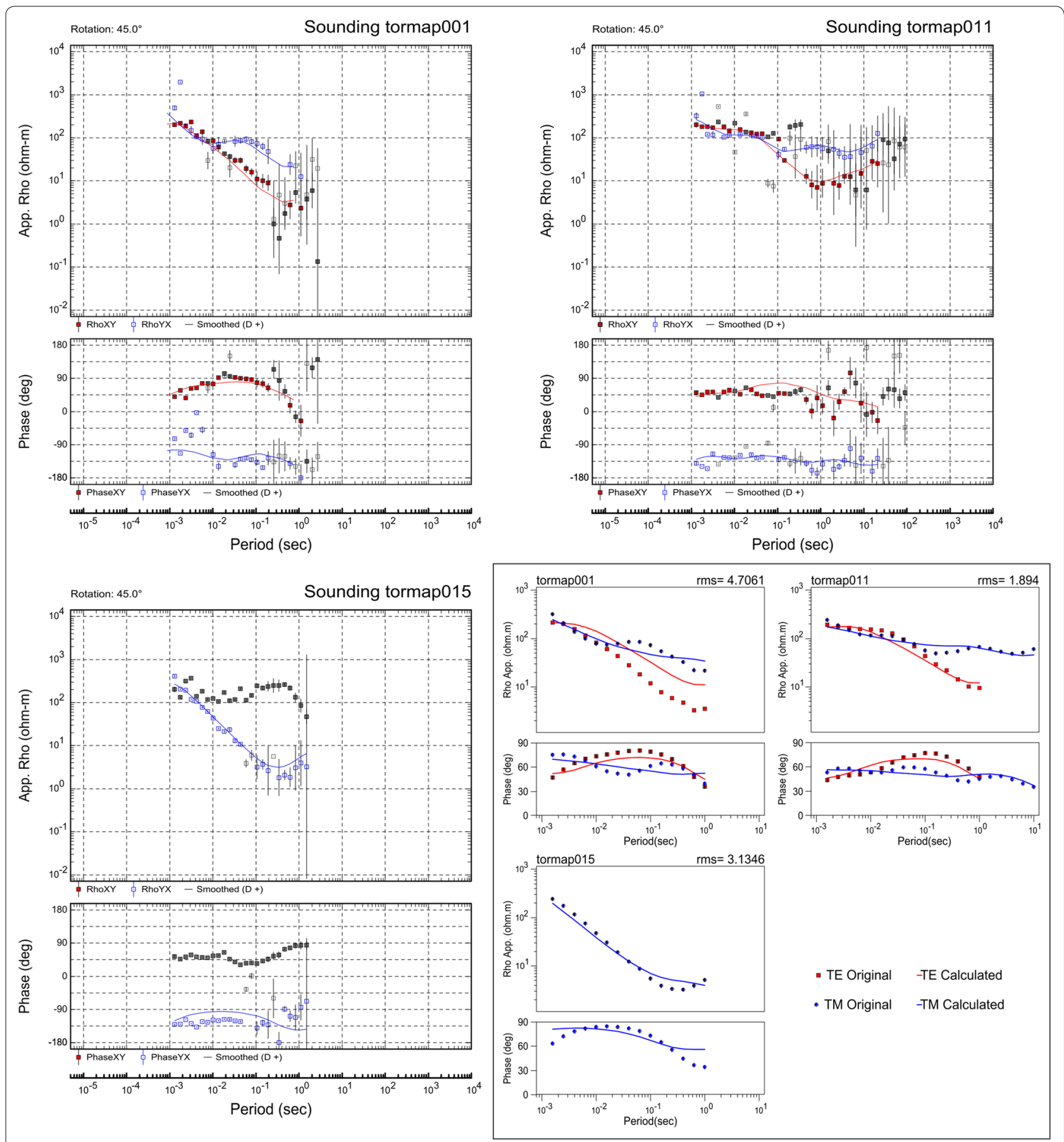

Fig. 8 Apparent resistivity and phases of the original data rotated by $45^{\circ}$ (symbols) and smoothed curves after applying D+ (solid lines) for Sites 1,11 and 15. Red and blue symbols were the ones used to apply the smoothing. Gray symbols correspond to frequencies that were deactivated. Inbox: TE and TM smoothed apparent resistivities and phases and 2D model responses for sites 1,11 and 15

Several tests were done by inverting the full dataset. However, given the low quality of the data at some sites and the short distance between them, this did not allow for the inversion process to adjust all the curves, or it produced conductivity artifacts at very large depths. Ultimately, we used 10 sites for the inversion.

A 10\% error was applied to the apparent resistivities with a $5^{\circ}$ error in the phases (both TE and TM). First we inverted the TM mode between $0.001 \mathrm{~s}$ and up 

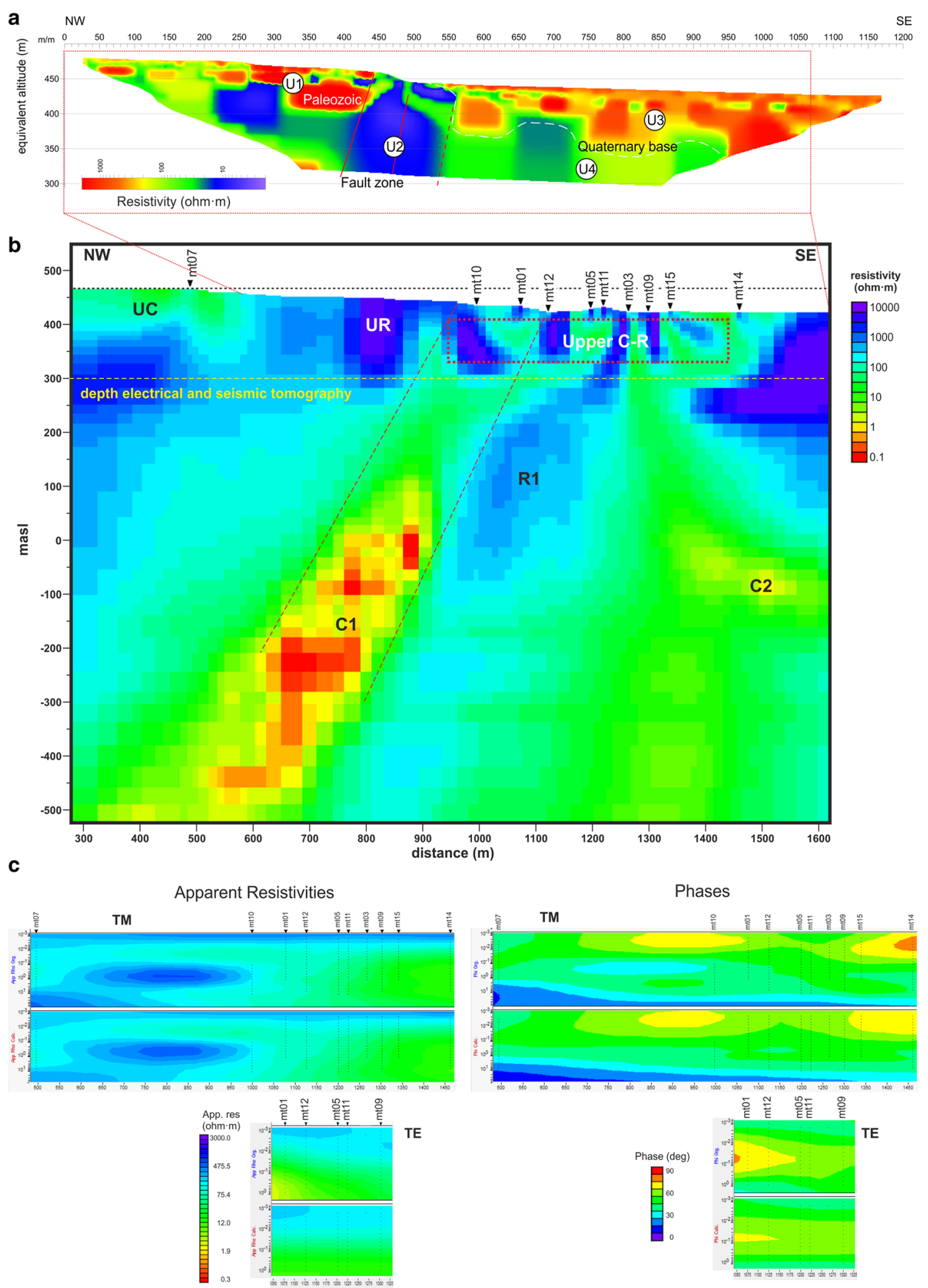

Fig. 9 a ERT model obtained for the La Torrecilla profile. Modified from Ardanaz et al. (2018). b Geoelectrical model obtained from the inversion of TE and TM magnetotelluric data with its main conductors and resistors identified. UC: upper conductor; UR: upper resistor; Upper C-R: upper conductor-resistor alternation; C1: conductor 1; C2: conductor 2; R1 resistor 1. c Pseudosections of the apparent resistivity (left) and phase (right) TE and TM data and model responses (apparent resistivities and phases). The relative position between the ERT and magnetotelluric model sections are indicated by the red lines. Note that the resistivity scales are inverted from each other 
to $100 \mathrm{~s}$. The starting rms was 12.41 ; it reached a value of 2.18 after 200 iterations. Departing from this model, we added data from the TE mode and inverted both jointly. For some of the sites, the TE mode could not be fitted. Hence, we did not consider this mode for Sites 3, 10 , and 15 . For the remaining sites, we inverted the TE mode up to $1 \mathrm{~s}$. We also refined the mesh to 105 rows and 116 columns. The first inversion led to large and very extreme conductivity values, which we removed as outliers, then fixed the Paleozoic base (resistivity of $200 \Omega \cdot \mathrm{m}$ ) at -500 m.a.s.l., before recalculating the responses. The resulting model (Fig. 9b) has an rms of 2.9 and shows geoelectrical structures down to depths of -500 m.a.s.l., therefore extending the depths able to be imaged by the ERT survey (Fig. 9a, inverted resistivity scale). Data and model responses are represented in Fig. 8 for Sites 1, 11, 15; and in Additional file 2: Figure S2-2, for the rest of the sites. Figure 9 also shows the TE and TM data and model responses pseudosections.

In its upper part, from NW to SE, the model shows a conductive zone (upper conductor, $\mathrm{UC}, 50 \Omega \cdot \mathrm{m}$ ), a very resistive zone (upper resistor, $\mathrm{UR}, 1000-10,000 \Omega \cdot \mathrm{m}$ ) and an alternation of resistors and conductors (Upper $C-R$, $50 \Omega \cdot \mathrm{m} / 5000 \Omega \cdot \mathrm{m})$. Below these, a very conductive zone $(C 1,0.1-1 \Omega \cdot \mathrm{m})$ that extends to a depth of -500 m.a.s.l., a resistor $(R 1,100-200 \Omega \cdot \mathrm{m})$ and a conductor $(C 2$, $5-20 \Omega \cdot \mathrm{m})$ are identified.

We carried out sensitivity tests for the Upper $C-R$, and for the conductor $C 1$, to assess if these structures are necessary to fit the data. For the Upper $C-R$, one of the objectives was also to see if the alternation of conductors was an inversion artifact or not and we substituted this structure for a single block of $1000 \Omega \cdot \mathrm{m}$. The recalculation of the forward problem led to an $\mathrm{rms}$ value of 10.3. From there, we ran the inverse problem again and recovered the Upper $C-R$ structure (see Additional file 2: Figure S2-3). Regarding C1, we modified its resistivity to $50 \Omega \cdot \mathrm{m}$ and to $200 \Omega \cdot \mathrm{m}$ and run the forward problem for each case, leading to rms values of 3.5 and 3.8 , respectively, and to a poor fit between the data and model responses-especially for sites located just above the conductor $C 1$ (see Additional file 2: Figure S2-4). Hence, both tests confirm that both the Upper $C-R$ and $C 1$ structures are required by the model in order to fit the data.

\section{D geoelectrical model of the AMF in the Torrecilla area}

The dimensionality analysis results (Fig. 7) show that the measured MT data corresponds mainly to 3D structures. For that reason we inverted it using the 3D code ModEM, using the $\mathrm{qZ}$ and the ZI responses separately.

First we inverted the data using a NS-EW oriented mesh, using all sites (except for those located on the other side of the highway: Sites 4 and 13). The details of the mesh inversion parameters and the resulting models, from both $\mathrm{ZI}$ and $\mathrm{qZ}$ are described in Additional file 3A. These models are characterized by much shallower structures than the 2D model but show a conductive body below the central part, which we identify as $C 1$. However, these models were limited by having all the sites located along only one profile (which may not be able to properly resolve the $3 \mathrm{D}$ structures); this profile is oblique to the approximated geoelectric strike (Kiyan et al. 2014), and can hence lead to incorrect recovery of the structures.

To avoid these effects, we performed a second set of inversions, this time with a rotated mesh, for which most of the sites would therefore be aligned. We also worked with the same sites as the ones used for the $2 \mathrm{D}$ inversion. Hence, we had to rotate both the grid and the data $40^{\circ} \mathrm{NE}$ (which was the direction with most of the sites along the same row).

We initially inverted the $\mathrm{qZ}$ data by departing from a homogeneous model. That led us to a model that had shallow structures with a conductive region below Sites 1,10 , and 12 . Next we generated a new starting model by extending the $2 \mathrm{D}$ model to all the vertical layers, and started a new inversion using the off-diagonal components (See mesh, inversion parameters, and data details in Additional file 3B). A cross section of the resulting model is shown in Fig. 10. We have labeled the conductive features as for the 2D model. Most of them (UR, Upper $C-R, C 1$, and $R 1$ ) have been preserved in the $3 \mathrm{D}$ model, whereas the shallow conductor (UC) was displaced towards the SE, which may be due to the low data coverage; the conductor $\mathrm{C} 2$ is not imaged.

The main conductive and resistive structures from the 2D model (Fig. 9b) and the cross section of the 3D model (Fig. 10) have been interpreted by taking into account the units (U1-U4) imaged by the ERT model (Fig. 9a).

We associate the shallow resistor UR with the Paleozoic materials of the Alpujárride Complex (phyllite with schists, Unit U1). The conductor UC, for which its location is not well constrained, would belong to the same geological complex but its lower resistivity might in fact be caused by a change in lithology or to the presence of conductive mineralization, i.e., graphite. We interpret the alternation of conductors and resistors (Upper $C-R$ ) as due to shallow levels of very dry colluvial materials (resistive, Unit U3) cut by vertical faults (conductive). We associate the main conductor $C 1$ with the main fault zone, likely a continuation in depth of the highly conductive Unit U2. Its low resistivity indicates the presence of highly fractured materials and fluid circulation, associated with the shear zone. This conductor defines a region with about $70^{\circ}$ of inclination (red dotted line in Fig. 9b) that delimits the fault zone. Resistor $R 1$ may correspond 


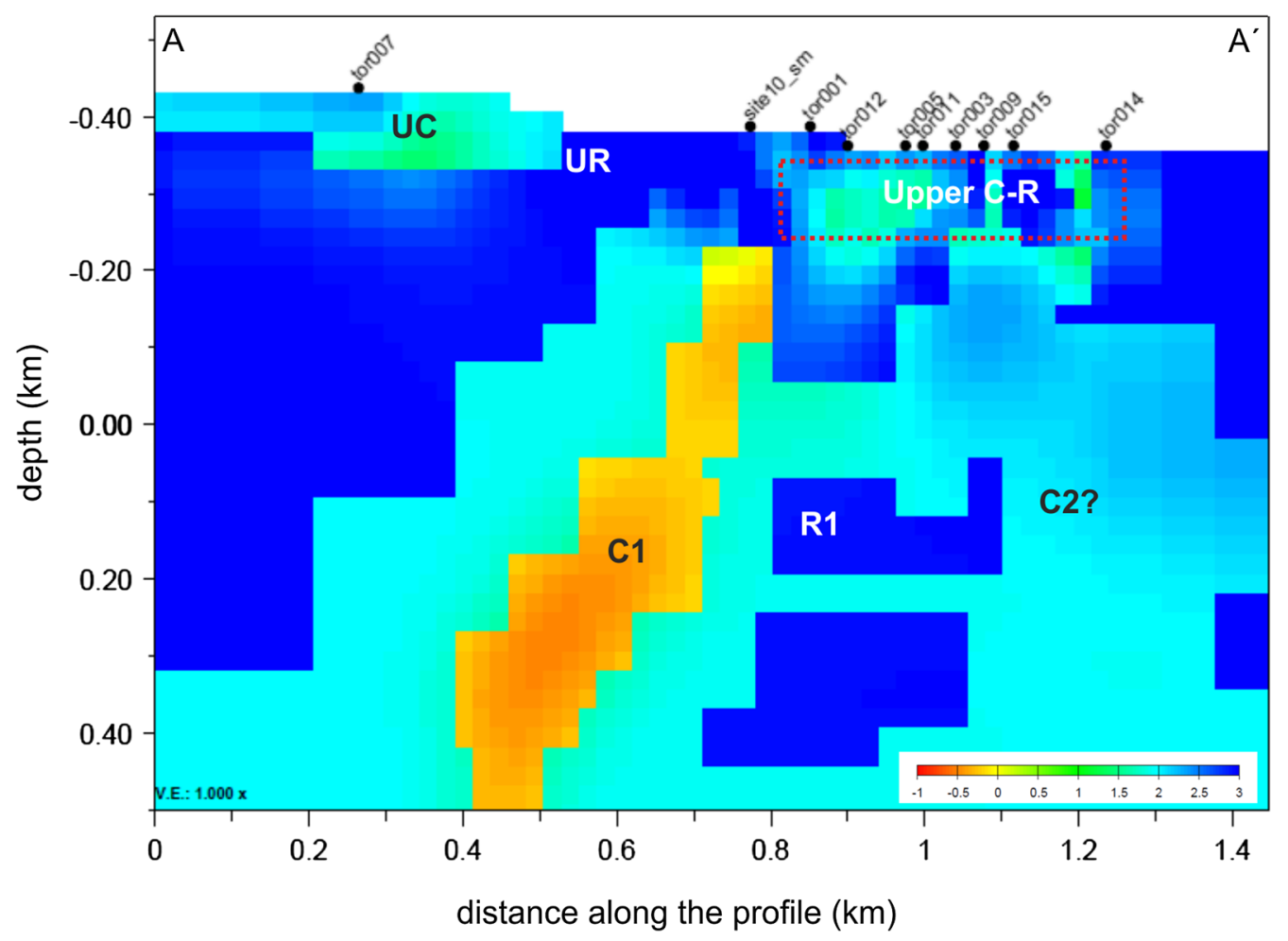

Fig. 10 Cross section of the model obtained from the inversion of qZ departing from the 2D model and extended to the full 3D mesh. Resistivity is indicated in decimal logarithmic scale

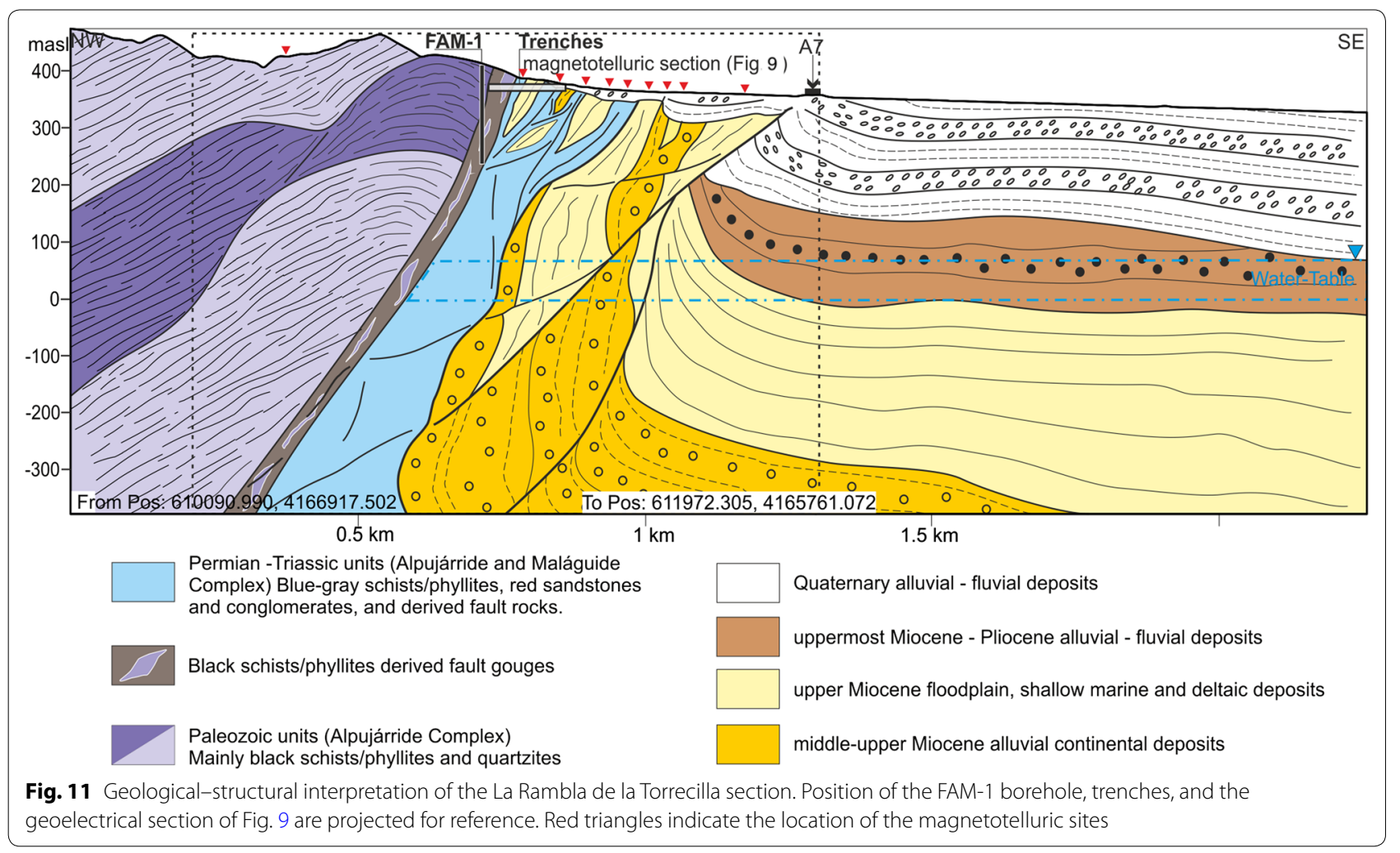


to the presence of the metamorphic basement, although it is difficult to prove given its geometry. Finally, conductor $\mathrm{C} 2$ is not identified in the 3D model, but may be interpreted as plio-quaternary materials and/or to the presence of marls with alternating sandstones, clay, and Miocene conglomerates.

\section{Discussion}

Combining the surface geological information, the information extracted from borehole FAM-1, and the trenches excavated across the fault zone (Martínez-Díaz et al. 2016b; Rodríguez-Escudero 2017) with the magnetotelluric analysis presented in this work, as well as the ERT profile, we interpret the detailed structure of the fault zone up to $1 \mathrm{~km}$ deep, as shown in Fig. 11. Geoelectrical models confirm the existence of a fault zone with a fairly uniform dip towards the NW up to at least $1 \mathrm{~km}$ depth, with a width of the main shear zone-where most of the deformation is concentrated-of at least $100 \mathrm{~m}$. This is expressed in the form of important lithological and structural heterogeneity inside this band. Previous studies carried out in the shear zone at microscopic, meter, and decameter scales support the existence of a clear scaleindependent geometry of the deformation fabric, one that is dominated by sigmoidal blocks of different lithologies and is controlled by Riedel and $Y$ planes from the shear zone (Rodríguez-Escudero et al. 2012; RodríguezEscudero 2017). This structural style is maintained at the hectometer scale interpreted in the cross section, assuming an evident uncertainty in the size and lithology of each tectonic block. The geophysical logging carried out in the FAM-1 borehole crossing the principal displacement zone (Martínez-Díaz et al. 2016b) shows very low permeability values along this zone dominated by a fault gouge band that is $\sim 20 \mathrm{~m}$ thick (dark gray band bounding the basement block in Fig. 11). Added to this is the fact that the water table level observed in several wells close to the area (penetrating the La Torrecilla alluvial fan for hydrogeological purposes) oscillates between 1 and 70 m.a.s.l. over the last 10 years (IGME 2019). This supports the interpretation that the minimum resistivity values shown by the MT survey located below sea level are related to the presence of water. It is also favored for the fault zone by the barrier effect exerted by the fault gouge.

The subsurface information also supports the possibility that the deformation zone associated with the AMF may reach a thickness of several hundred meters. Its southeast edge bounds a net thickness change of Quaternary dry alluvial deposits in the La Torrecilla alluvial fan. This points to the existence of a fault that would therefore be located close to the A7 highway. This structure therefore would have special significance for the seismic hazard potential of the region since its continuation towards the NE, assuming a trend similar to that observed for the outcropping fault zone, would pass below or very close to the Rafael Mendez General Hospital (Figs. 1 and 6). This underscores the importance of intensifying the geophysical studies in this sector of the AMF.

\section{Conclusions}

We carried out a magnetotelluric study for the GóñarLorca sector of the Alhama de Murcia Fault in order to reveal its structure at depth. At some sites only the electric field was measured, and the responses (Interstation Impedances) were obtained from the magnetic fields of neighboring sites.

Using synthetic models that represent a fault zone, we evaluated the inversion of interstation impedances $(Z I)$, impedances $(Z)$, and quasi-impedances (qZ). The inversions of $Z$ or ZI recover models with comparable resistivity structures. The inversion of the quasi-impedance (qZ) does not reproduce all the structures depending on the location of the magnetic field, but in general it still provides a valid model.

Despite the challenges arising from noise in the data, the 2D and 3D models reveal structures that correlate well with previous geophysical and geological information and complementing them with depth. The main feature is the presence of a $70^{\circ} \mathrm{NW}$ dipping conductor, which we associate with the main fault gouge. Its high conductivity is explained by high fracturation and to the presence of fluids.

\section{Supplementary information}

Supplementary information accompanies this paper at https://doi. org/10.1186/s40623-020-1143-2.

Additional file 1. Details of the synthetic models.

Additional file 2. Data, 2D model responses and sensitivity tests.

Additional file 3. 3D inversion details, data and model responses.

\section{Abbreviations}

AMF (FAM): Alhama de Murcia Fault; Mw: Moment magnitude scale; Z: Impedance tensor; ZI: Interstation impedance tensor; qZ: Quasi-impedance tensor; TE: Transversal electric; TM: Transversal magnetic; rms: Root mean square.

\section{Acknowledgements}

We greatly acknowledge the editor Dikun Yang and two anonymous reviewers for their valuable suggestions, which helped us improve the manuscript. We thank Gary Egbert and Anna Kelbert for providing the ModEM code. We thank Teresa Teixidó for providing ERT models. English proofreading was by Grant George Buffett, http://www.terranova.barcelona.

\section{Authors' contributions}

AM and PQ acquired, processed, analyzed, and modeled the magnetotelluric data from Torrecilla. AM and JL participated in the processing and analysis of the data. JJMD lead the project and JJMD and ERE defined the geological setting, and contributed to the interpretation of the models from Torrecilla. $A M, P Q, J C$, and NM analyzed and discussed the results from the $Z, Z I$, and $q Z$ 
inversions. AM wrote the main manuscript. All authors read and approved the final manuscript.

\section{Funding}

This research was funded by the INGERGEOSIMA project: CGL2013-47412 from the Ministerio de Economía y Competitividad of the Spanish Government and by project CGL2017-82169-C2-2-R from Agencia Estatal de Investigación (AEI) of the Spanish Government and Fondo Europeo de Desarrollo Regional (FEDER).

\section{Availability of data and materials}

The magnetotelluric dataset used during the present study is available from the corresponding author upon reasonable request.

\section{Ethics approval and consent to participate}

Not applicable.

\section{Consent for publication}

Not applicable.

\section{Competing interests}

The authors declare that they have no competing interests.

\section{Author details}

${ }^{1}$ Institut Geomodels, Departament de Dinàmica de la Terra i de l'Oceà, Facultat de Ciències de la Terra, Universitat de Barcelona, 08028 Barcelona, Spain. ${ }^{2}$ Departamento de Geodinámica, Estratigrafía y Paleontología, Universidad Complutense de Madrid, 28040 Madrid, Spain. ${ }^{3}$ Instituto de Geociencias IGEO, Centro Mixto del Consejo Superior de Investigaciones Científicas (CSIC) y de la Universidad Complutense de Madrid (UCM), 28040 Madrid, Spain. ${ }^{4}$ Contractor, Geological Survey Ireland, Beggars Bush, Haddington Road, Dublin, Ireland. ${ }^{5}$ National Observatory of Brazil, Rio de Janeiro, Brazil. ${ }^{6}$ Consulting-GEO, Berlin, Germany.

Received: 29 June 2019 Accepted: 22 January 2020

Published online: 10 February 2020

\section{References}

Ardanaz O, Dávila L, Teixidó T, Martí D, Martí A, Queralt P, Rodríguez-Escudero E, Camacho J, Martínez-Díaz J, Carbonell R (2018) Geophysical characterization of the Alhama de Murcia Fault in the Torrecilla sector. III Reunión Ibérica sobre fallas activas y paleosismologia (Iberfault). Alicante (Spain), 11-13 June 2018

Azañón JM, Galindo-Zaldívar J, García-Dueñas V, Jabaloy A (2002) Alpine tectonics II: Betic Cordillera and Balearic Islands. In: Gibbons W, Moreno T (eds) The geology of Spain. Geological Society, London

Beamish D, Travassos JM (1992) The use of the D+ solution in magnetotelluric interpretation. J Appl Geophys 29:1-19

Becken M, Ritter O (2012) Magnetotelluric studies at the San Andreas Fault Zone: implications for the role of fluids. Surv Geophys 33:65-105

Bousquet JC (1979) Quaternary strike-slip faults in southeastern Spain. Tectonophysics 52:277-286

Caldwell TG, Bibby HM, Brown C (2004) The magnetotelluric phase tensor. Geophys J Int 158:457-469

Campanyà J, Ledo J, Queralt P, Marcuello A, Jones AG (2014) A new methodology to estimate magnetotelluric (MT) tensor relationships: estimation of Local transfer-functions by Combining Interstation Transfer-functions (ELICIT). Geophys J Int 198(1):484-494. https://doi.org/10.1093/gji/ggu14 7

Campanyà J, Ogaya X, Jones AG, Rath V, Vozar J, Meqbel N (2016) The advantages of complementing MT profiles in 3-D environments with geomagnetic transfer function and interstation horizontal magnetic transfer function data: results from a synthetic case study. Geophys J Int 207(3):1818-1836. https://doi.org/10.1093/gji/ggw357

Chave A, Jones A (2012) The magnetotelluric method. Theory and practice. Cambridge University Press, Cambridge

Echeverría A, Khazaradze G, Asensio E, Garate J, Martín-Dávila J, Suriñach E (2013) Crustal deformation in eastern Betics from CuaTeNeo GPS network. Tectonophysics 608:600-612
Egbert GD, Kelbert A (2012) Computational recipes for electromagnetic inverse problems. Geophys J Int 189:251-267. https://doi.org/10.1111/ j.1365-246X.2011.05347.X

Egeler CG, Simon OJ (1969) Sur la tectonique de la Zone Bétique (Cordillères Bétiques) Espagne). Verhandelingen der Koninklijke Nederlandse Akademie van Wetenschappen 25: $90 \mathrm{pp}$

Escalas L, Queralt P, Ledo JJ, Marcuello A (2013) Polarisation analysis of magnetotelluric time series using a wavelet-based scheme: a method for detection and characterisation of cultural noise sources. Phys Earth Planet Interiors 218:31-50. https://doi.org/10.1016/j.pepi.2013.02.006

Ferrater M, Ortuño M, Masana E, Pallas R, Perea H, Baize S, Garia-Melendez E, Martínez-Díaz JJ, Echeverria A, Rockwell TK, Sharp WD, Medialdea A Rhodes EJ (2016) Refining seismic parameters in low seismicity areas by 3D trenching: the Alhama de Murcia fault, SE Iberia. Tectonophysics 680:122-128. https://doi.org/10.1016/j.tecto.2016.05.020

Friedrichs B (2003) MAPROS, Magnetotelluric processing software (Metronix). User manual

Friedrichs B (2015) ProcMT online manual. https://www.geo-metronix.de/ procmt_html/.Accessed 31st Oct 2019

Galindo Zaldívar J, González Lodeiro F, Jabaloy A (1989) Progresive extensional shear structures in a detachment contact in the western Sierra Nevada (Betic Cordilleras, Spain). Geodinamica Acta 3:73-85

Herrero-Barbero P, Álvarez-Gómez JA, Martínez-Díaz JJ (2018) Análisis estructural del segmento Alhama de Murcia - Alcantarilla de la Falla de Alhama de Murcia: Estimación de acortamiento y tasas de deslizamiento mediante cortes compensados. Resúmenes de la 3a Reunión Ibérica sobre Fallas Activas y Paleosismología, Alicante, España. pp 55-58. ISBN 978-84-09-02473-5

Instituto Geológico y Minero de España, IGME (2019) Database of water points http://info.igme.es/BDAguas/. Accessed 4 June 2019

Jabaloy A, Galindo-Zaldívar J, González Lodeiro F (1992) The mecina extensional system: its relation with the post Aquitanian piggy-back Basins and the palaeostresses evolution (Betic Cordilleras, Spain). Geo-Mar Lett 12:96-106

Kelbert A, Megbel N, Egbert G, Tandon K (2014) ModEM: a modular system for inversion of electromagnetic geophysical data. Comput Geosci 66:40-53. https://doi.org/10.1016/j.cageo.2014.01.010

Kirkby A, Zhang F, Peacock J, Hassan R, Duan J (2019) The MTPy software package for magnetotelluric data analysis and visualisation. J Open Sour Softw 4(37):1358. https://doi.org/10.21105/joss.01358

Kiyan D, Jones AG, Vozar J (2014) The inability of magnetotelluric offdiagonal impedance tensor to sense oblique conductors in threedimensional inversion. Geophys J Int 196:1351-1364. https://doi. org/10.1093/gji/ggt470

Kruglyakov M, Kuvshinov A (2019) 3-D inversion of MT impedances and inter-site tensors, individually and jointly. New lessons learnt. Earth Planets Space. https://doi.org/10.1186/s40623-018-0972-8

Larouzière FD, Bolze J, Bordet P, Hernández J, Montenat C, Ott D'Estevou P (1988) The Betic segment of the lithospheric Transalboran shear zone during the Late Miocene. Tectonophysics 152:41-52

López-Comino JA, Mancilla F, Morales J, Stich D (2012) Rupture directivity of the 2011, Mw 5.2 Lorca earthquake (Spain). Geophys Res Lett 39:L03301. https://doi.org/10.1029/2011gl050498

Martí A, Queralt P, Ledo J (2009) WALDIM: a code for the dimensionality analysis of magnetotelluric data using the rotational invariants of the magnetotelluric tensor. Comput Geosci 35:2295-2303

Martínez-Díaz JJ (1998) Neotectónica y tectónica activa del sector centrooccidental de la Región de Murcia y sur de Almería. PhD Thesis. Universidad Complutense de Madrid. $466 \mathrm{pp}$

Martínez-Díaz JJ, Masana E, Ortuño M (2012a) Active tectonics of the Alhama de Murcia fault, Betic Cordillera, Spain. J Iberian Geol 38(1):253-270

Martínez-Díaz JJ, Bejar-Pizarro M, Álvarez-Gómez JA, de Lis Mancilla F, Stich D, Herrera G, Morales J (2012b) Tectonic and seismic implications of an intersegment rupture. The damaging May 11th 2011 Mw 5.2 Lorca, Spain, earthquake. Tectonophysics 546:28-37

Martínez-Díaz JJ, Pérez-López R, Staller A, The InterGeosima Team (2016a) Multi-parametric monitoring of the Alhama de Murcia Fault. Geotemas 16:567-570

Martínez-Díaz JJ, Insua-Arévalo JM, Tsige M, Rodríguez-Escudero E, Jurado MJ, Alonso-Henar J, Crespo J, Jiménez-Molina D, Moratalla 
JM, Rodríguez-Péces MJ, Álvarez-Gómez JA, Pérez-López R, Alvaro M, Capote R (2016b) FAM-1 Borehole: first results from the scientific drilling of the Alhama de Murcia Fault, Betic Cordillera, Spain. Geotemas 16:579-582

Martínez-Díaz JJ, Alonso-Henar J, Insua-Arévalo JM, Canora C, García-Mayordomo J, Rodríguez-Escudero E, Álvarez-Gómez JA, Ferrater M, Ortuño M, Masana E (2018) Geological evidences of surface rupture related to a seventeenth century destructive earthquake in Betic Cordillera (SE Spain): constraining the seismic hazard of the Alhama de Murcia Fault. J Iberian Geol. https://doi.org/10.1007/s41513-018-0082-2

Martínez-Martínez JM, Azañón JM (1997) Mode of extensional tectonics in the southeastern Betics (SE Spain): implications for the tectonic evolution of the peri-Alborán orogenic system. Tectonics 16:205-225. https ://doi.org/10.1029/97tc00157

Montenat C (ed) (1990) Les Bassins néogénes du domaine bétique oriental (Espagne). Tectonique et sédimentation dans un couloir de décrochement. Premiére partie: étude régionale. Doc. et Trav. IGAL, París, 12-13, $1-392$

Montenat C, Ott d'Estevou P, Masse E (1987) Tectonic-sedimentary characters of the Betic Neogene basins evolving in a crustal transcurrent shear zone (SE Spain). Bulletin des centres de recherches explor Prod Elf-Aquitaine 11(1):1-22

Muñoz G, Ritter O (2013) Pseudo-remote reference processing of magnetotelluric data: a fast and efficient data acquisition scheme for local arrays. Geophys Prospect. https://doi.org/10.1111/1365-2478.12012

Ortuño M, Queralt P, Martí A, Ledo J, Masana E, Perea H, Santanach P (2008) The North Maladeta Fault (Spanish Central Pyrenees) as the Vielha 1923 earthquake seismic source: recent activity revealed by geomorphological and geophysical research. Tectonophysics 453:246-262

Ritter O, Ryberg T, Weckmann U, Hoffmann-Rothe A, Abueladas A, Garfunkel Z, DESERT Research Group (2003) Geophysical images of the Dead Sea Transform in Jordan reveal an impermeable barrier for fluid flow. Geophys Res Lett 30(14):1741. https://doi.org/10.1029/2003GL017541

Rodi W, Mackie RL (2001) Nonlinear conjugate gradients algorithm for 2-D magnetotelluric inversion. Geophysics 66:174-187
Rodríguez-Escudero E (2017) Implicaciones de la estructura interna de una zona de falla activa en la génesis de terremotos. PhD Thesis. Universidad Autónoma de Madrid. Madrid. 304 pp

Rodríguez-Escudero E, Martínez-Díaz JJ, Tsige M (2012) Deformaciones dúctiles en régimen frágil en una falla activa lenta: La falla de Alhama de Murcia. Implicaciones sismotectónicas. Geotemas 13:1531-1534 (ISSN: 1576-5172)

Rodríguez-Escudero E, Niemeijer A, Martínez-Díaz JJ, Giner-Robles JL, Tsige M, Insua-Arévalo JM, Cuevas-Rodríguez J (2018) Propiedades mineralógicas y friccionales de la gouge de la Falla de Alhama de Murcia (SE España): implicaciones sismogénicas. Resúmenes de la 3a Reunión Ibérica sobre Fallas Activas y Paleosismología, Alicante, España. pp 191-194. ISBN 978-84-09-02473-5

Silva P (1994) Evolución geodinámica de la Depresión del Guadalentín desde el Mioceno Superior hasta la actualidad: neotectónica y geomorfología. PhD Thesis. Universidad Complutense de Madrid, pp 642

Silva PG, Goy JL, Somoza L, Zazo C, Bardaji T (1993) Landscape response to strike-slip faulting linked to collisional settings: quaternary tectonics and basin formation in the Eastern Betics, southeastern Spain. Tectonophysics 224:289-303

Staller-Vázquez A, Martínez-Díaz JJ, Pérez-López R, Khazaradze G, Béjar-Pizarro M, Álvarez-Gómez JA, Alonso-Henar J, Insua-Arévalo JM, Valdés M, Sánchez-Sobrino, JA, Azcue E, Gonzalo P (2018) Monitorización geodésica de las zonas de falla de Alhama de Murcia, Palomares y Carrascoy (Zona de Cizalla de las Béticas Orientales): trabajos en marcha. Resúmenes de la 3a Reunión Ibérica sobre Fallas Activas y Paleosismología, Alicante, España. pp 199-202. ISBN 978-84-09-02473-5

\section{Publisher's Note}

Springer Nature remains neutral with regard to jurisdictional claims in published maps and institutional affiliations.

\section{Submit your manuscript to a SpringerOpen ${ }^{\circ}$ journal and benefit from:}

- Convenient online submission

- Rigorous peer review

- Open access: articles freely available online

- High visibility within the field

- Retaining the copyright to your article

Submit your next manuscript at $\boldsymbol{\nabla}$ springeropen.com 